Dynamics in ownership and firm survival:

Evidence from corporate Germany

Florian Heiss and Jens Köke

13-2002

January 2002 


\title{
Dynamics in ownership and firm survival: Evidence from corporate Germany
}

\author{
FLORIAN HEISS $\ddagger$ \\ University of Mannheim, MEA \\ JENS KÖKE ${ }^{\S}$ \\ Centre for European Economic Research and \\ University of Mannheim, MEA
}

December 2001

$\ddagger$ email: heiss@econ.uni-mannheim.de

$\S$ Address for correspondence: University of Mannheim, MEA, L13,17, 68131 Mannheim, Germany; email: koeke@zew.de

Acknowledgements: We appreciate helpful comments from Axel Börsch-Supan, Peter Westerheide, Joachim Winter, as well as from participants of the annual meeting of the European Economic Association in Lausanne, participants of the annual meeting of the Verein für Socialpolitik in Magdeburg, and participants of research seminars at the University of Mannheim. Financial support from the German Science Foundation (DFG) is gratefully acknowledged (grant no. BO 934, 71). Matthias Braun, Gregor Führich, and Heiko Truppel provided excellent research assistance. Finally, we thank Dirk Günnemann for editorial assistance. 


\begin{abstract}
:
This study investigates the determinants of changes in corporate ownership and firm failure, taking into account different types of sellers and buyers of control blocks. For a large panel of German corporations we find that firms are more likely to fail or to be sold when performance is poor, financial pressure is high, and firm size is small. Cross-ownership deters control changes, and ownership concentration has a non-linear impact on the likelihood of control transfer. In contrast to corporate shareholders, private shareholders tend to sell control blocks when financial pressure increases.
\end{abstract}

Keywords: Corporate governance, ownership structure, bankruptcy, takeover JEL classification: G32, G33, G34 


\section{Introduction}

Dynamics in firm ownership are beginning to form a new element in the complex corporate governance framework. Transfers of corporate control occur more frequently than often assumed because the usual emphasis lies on hostile takeovers rather than block acquisitions. For the US, Barcley and Holderness (1991) report that during the years 1978-1982 the number of registered block trades was about twice as high as the number of tender offers. Bethel et al. (1998) document that firms from the Fortune 500 list are three times as likely to experience a block acquisition by an activist investor than a hostile takeover or leveraged buyout. In Germany and in other continental European countries, hostile takeovers are rare (Franks and Mayer, 1998), but the frequency of block trades is comparable to the US (see Franks and Mayer, 2001, for Germany; see Renneboog, 2000, for Belgium).

Along with evidence on the frequency of changes in corporate control, evidence is accumulating on the causes of control transfers. Poor performance (Denis and Sarin, 1999; Maksimovic and Phillips, 2001), high financial pressure (Zingales, 1998), and economic shocks (Denis and Sarin, 1999) are identified as factors that make control transfers more likely. In turn, not adapting governance structures can make firm failure more likely (Kole and Lehn, 1999). However, evidence on the transactions themselves, in particular the identity of trading partners of control blocks, is sparse. Previous studies limit their attention to changes in managerial ownership and the associated consequences for a firm (Kole and Lehn, 1999; Denis and Sarin, 1999), or the effects of block purchases by activist, financial, and strategic investors (Bethel et al., 1998). To our knowledge, there is no study that analyzes simultaneously which type of shareholder is more likely to buy or to sell control blocks. Likewise, prior research does not examine whether firm-specific characteristics vary in their impact on the probability of control transfers, in particular whether their impact depends on the type of seller or buyer of those control blocks.

This study aims to provide a better understanding of the determinants of firm 
failure and control transfers, in particular the role of the type of controlling shareholders. The analysis is based on a sample of over 1,500 large and medium-sized German corporations for the years 1986-1995. We find that, irrespective of the type of the controlling shareholder, firms are both more likely to fail and to experience a change in ownership when performance is poor, financial pressure is high, and firm size is small. In contrast, complex ownership structures, reflected for example in cross-ownership, reduce the likelihood of a control transfer. Concerning the type of seller, we find that the impact of ownership concentration on the likelihood of a control sale is non-linear. More precisely, for firms that do not have a dominant shareholder the likelihood of control change increases with share concentration, but it decreases for firms that are under control of a dominant shareholder. In combination, this suggests that firms with medium share concentration are most likely to be acquired. In addition, a private owner is more likely than a corporate owner to sell a firm under financial pressure. Regarding the type of buyer, we find that larger firms are most likely to be sold to the government or to the public, but least likely to a private shareholder.

Understanding the determinants of ownership change is important. Recent evidence from the US suggests that changes in ownership have a disciplinary function for poorly performing firms because they significantly increase the rate of asset divestitures or employee layoffs (Bethel et al., 1998; Denis and Kruse, 2000), management turnover (Kole and Lehn, 1999), and corporate refocusing (Berger and Ofek, 1999). Therefore, our finding that poor performance makes a change in ownership more likely indicates that control transfers could represent a vehicle for managerial disciplining also for Germany. Note that Franks and Mayer (2001) cannot confirm such a governance role for ownership changes. Using a sample of 75 German firms over the years 1989-1994 they find that block sales make management turnover more likely, however irrespective of whether performance is good or bad.

This study proceeds as follows. Section 1 provides a short overview of the theoretical and empirical literature on the determinants of firm failure and control changes 
as well as the role of different types of buyers and sellers in control transactions. The literature is condensed into a set of hypotheses which are tested in the empirical analysis. Section 2 describes the data used in this study and the frequency of failure and control changes. It also gives some preliminary evidence on the causes of failures and changes in control based on descriptive statistics. Section 3 examines the determinants of control transfers and failure in a multivariate framework. Subsequently, we investigate this issue by (a) neglecting the types of owners of control blocks, (b) examining the type of seller, and (c) examining the type of buyer. Section 4 concludes.

\section{Literature and resulting hypotheses}

To structure our empirical analysis of dynamics in corporate ownership and firm survival, we formulate a set of hypotheses based upon the existing theoretical and empirical literature. These hypotheses relate to predictions concerning the determinants of control transfers and firm failure (Section 1.1) and predictions concerning which type of investor is likely to sell (Section 1.2) or to buy a company (Section $1.3)$.

\subsection{Control transfers and firm failure}

Concerning the likelihood of a control transfer and firm failure we hypothesize:

Hypothesis C1: Control transfers and failure are more likely for firms with poor performance.

Hypothesis C2: Control transfers and failure are more likely for firms with high financial pressure.

Hypothesis C3: Control transfers are less likely for firms with very high or very low concentration of ownership, and failure is less likely for firms with high ownership concentration. 
Hypothesis C4: Control transfers and failure are less likely for firms with complex ownership structures.

Hypothesis C5: Control transfers and failure are less likely for large firms.

The current theoretical view of control transfers is largely shaped by two conflicting effects of blockholder control (Kahan, 1993; Bebchuk, 1994). On the one hand, transferring control to a more effective management team could improve efficiency. On the other hand, the acquirer's primary motive may be to loot the firm to the disadvantage of small shareholders. Empirical evidence on the consequences of changes in control suggests that they bring about improvements (Barcley and Holderness, 1991). The evidence also indicates that changes in control occur more often when performance is poor; for the US, see Bethel et al., 1998, Denis and Sarin, 1999, and Maksimovic and Phillips, 2001; for the UK, see Franks et al., 1999; and for Germany, see Köke, 2000). Similarly, a number of studies suggests that performance is a useful predictor for firm failure (e.g., Altman, 1968; Powell, 1997; Astebro and Winter, 2001). Hence, we expect that control transfers and firm failure are more likely when performance is poor $(\mathbf{C 1})$.

The second hypothesis (C2) considers the role of capital structure. Mitchell and Mulherin (1996) argue that changes in the firm's growth opportunities or leverage could make adjustments in ownership necessary. Consistent with this view, Zingales (1998) reports that following deregulation in the US trucking industry in 1977 firms were confronted with increasing leverage, and that this has led to a higher probability of market exit. Other empirical studies on firm failure confirm this role of financial pressure (Altman, 1968; Powell, 1997). Thus, firms with high financial pressure should be more likely to become subject to a takeover or failure.

The third hypothesis (C3) states that ownership concentration has an inversely U-shaped impact on the likelihood of a control transfer and a negative impact on failure. Grossman and Hart (1980) argue that a precondition for effective hostile takeovers is concentrated share ownership because shareholders would prefer to 
free-ride under dispersed ownership. Similarly, Burkart et al. (2000) show that the incumbent and the new controlling shareholder prefer to trade a block rather than sell shares to the public and, in a second step, accumulate those dispersed shares because they anticipate the free-riding behavior of small shareholders associated with tender offers. Hence, an ex ante larger concentration of shares should make control transfers more likely. In contrast, Holmström and Tirole (1993) argue that takeovers require low concentration of ownership and high market liquidity because only then are capital markets able to determine the necessity of a takeover. The few cases of hostile takeovers in Germany support Holmström and Tirole: In all cases the shares of the takeover target were widely dispersed (Franks and Mayer, 1998). However, the significant number of non-hostile control transfers in Germany indicates that block trades occur despite of typically large share concentration, which is typical for German corporations (Köke, 2000; Jenkinson and Ljungqvist, 2001). In sum, we expect the costs of a takeover to be the largest for both very high and very low concentration of ownership. The impact of share concentration on firm failure is less ambiguous. Higher concentration implies that the scope for agency conflicts is reduced, and hence large shareholders can alleviate the agency problem via better monitoring (Shleifer and Vishny, 1986). Therefore, the likelihood of failure should decline in ownership concentration.

The fourth hypothesis (C4) considers the complexity of ownership as a barrier to control transfers or failure. Managers of pyramid firms are probably more likely to resist the sale of control when selling parts of such a conglomerate implies a loss of organizational capital. Likewise, pyramids can manifest managerial empires and as such have a value to managers (Franks and Mayer, 1995). Similarly, cross-ownership could deter changes in control (Adams, 1994; Wenger and Kaserer, 1998; Bebchuk et al., 2000). We also expect failure to be less likely for firms that are part of pyramids or are controlled by cross-owned shareholders because information asymmetries should be smaller within such organizational structures, and therefore financial aid easier accessible. Besides, empire building could also prevent management from closing 
down firms even in mature industries (Jensen, 1986).

The fifth hypothesis (C5) establishes that firm size makes control transfers or failure less likely. Shleifer and Vishny (1992) argue that the market for corporate control is less liquid as firm size increases. Bethel et al. (1998) and Mulherin and Boone (2000) provide empirical evidence that smaller firms are more likely to become takeover targets. Concerning firm failure, bankruptcy should be less likely for very large firms. If very large firms get into financial trouble, this might give management the opportunity to be eligible for help from outside creditors or the government. Such firms can be too big to let them fail. A recent example is the case of the construction conglomerate Holzmann AG. After having come into severe financial difficulties in the year 2000, creditors agreed - under the lead of German chancellor Schröder - to extend existing credits to Holzmann by another 2 billion DM.

\subsection{Control transfers: the type of sellers}

Taking into account different types of sellers of control blocks, we hypothesize:

Hypothesis S1: A poorly performing firm is less likely to be sold when owned by a private shareholder than when owned by a corporate shareholder, but most likely when no dominant shareholder exists.

Hypothesis S2: A firm facing financial pressure is less likely to be sold when owned by a corporate shareholder than when owned by a private shareholder, but least likely when no dominant shareholder exists.

The first hypothesis (S1) argues that poor performance has a different impact on the likelihood of a control transfer, depending on the type of the seller. Since private owners are often not only financially deeply involved in the respective firm, for example because they belong to the founding family, a private owner should be less likely than a corporate owner to sell a poorly performing firm. In contrast, we expect that a poorly performing firm not having a dominant shareholder (i.e. having 
a dispersed shareholder base) is even more likely to be sold because an incoming strong shareholder should be able to fix governance problems. Similarly, Holmström and Tirole (1993) argue that acquisitions should be more likely when ownership is not concentrated.

The second hypothesis (S2) follows from considerations that different types of shareholders have different access to financial resources. If a firm faces high financial pressure, reflected for example in a large burden of debt or low liquidity, we expect a private owner to be most likely to sell because of wealth constraints. In contrast, a corporate owner often commands over an internal capital market which can be used to transfer cash between divisions; see Lamont (1997) for evidence from the US oil industry. Firms without a dominant shareholder should be least likely to sell because they can issue further shares to the public to ease liquidity problems.

\subsection{Control transfers: the type of buyers}

Taking into account different types of buyers of control blocks, we hypothesize:

Hypothesis B1: If a poorly performing firm is sold, then it is most likely to be sold to a corporate shareholder, less likely to a private shareholder, and least likely to the public.

Hypothesis B2: If a firm under financial pressure is sold, then it is most likely to be sold to the public, less likely to a corporate shareholder, and least likely to a private shareholder.

Hypothesis B3: If a large firm is sold, then it is most likely to be sold to the public, less likely to a corporate shareholder, and least likely to a private shareholder.

The first hypothesis (B1) establishes that poor performance has a different impact on the likelihood of a control transfer, depending on the type of buyer. Barcley and Holderness (1991) show that stock prices react positively to a change in the identity of the blockholder. However, we argue that efficiency gains depend on the type of the 
buyer of the control block. If performance is poor, a company should be more likely to be bought by an investor that has a superior monitoring technology. Examples of such a technology are knowledge of the respective industry, knowledge of how to detect deficiencies in an inefficiently governed takeover target, or knowledge of how to conduct corporate restructuring. Since these kinds of knowledge are typically acquired only in business practice, we expect financial firms (such as banks) and non-financial firms to be most able to realize any such efficiency gains. In contrast, poorly performing firms should be less likely to sell previously concentrated shares to several large or many small investors (henceforth: the public) because this would create the well-known free-rider problem (Grossman and Hart, 1980; Shleifer and Vishny, 1986). Hence, bringing the organization back on track would be even more difficult without a strong controlling shareholder.

The second hypothesis (B2) considers the impact of financial pressure. If a firm's debt burden is high or liquidity is low, a corporate shareholder should be more likely to buy this firm than a private shareholder. The reason is that private shareholders are typically more wealth-constrained than corporate shareholders. However, when

liquidity is poor, selling shares to the public should be an even better alternative than selling to another firm, in particular in the wake of major investment programs (Pagano and Röell, 1996).

Finally, the third hypothesis (B3) focuses on firm size. Firm size can reduce the likelihood of acquisition (Bethel et al., 1998; Mulherin and Boone, 2000). Therefore, due to wealth constraints private shareholders should be least likely to buy large firms. In turn, large firms should be most likely to be sold to the public.

\section{Data description}

The sample comprises 7,577 observations relating to 1,510 firms over the years 19861995. For all firms, the data set contains annual information on firm performance, capital structure, ownership structure, and firm size. The panel is unbalanced in the 
sense that firms can enter the sample after the year 1986 and exit the sample before 1995.

More specifically, the data set contains medium-sized and large German corporations, about half of which are non-listed (Table 1). Taking the number of all German corporations in the year 1992 as a benchmark, listed firms are well-covered $(68.9 \%$ of all listed firms). In fact, the sample includes almost all corporations listed on any German stock exchange, excluding firms in the financial service industries and firms under strict government regulation such as utility, traffic, and telecommunications; see also Appendix A. Sample firms operate under three different legal forms: public corporations (AG and, to a much smaller extent, KGaA) and private corporations $(\mathrm{GmbH})$. Coverage of non-listed corporations is much weaker, in particular for GmbH firms (0.03\% of all GmbH firms). However, choosing corporations with total sales exceeding 100 million DM as the benchmark, we find that the sample contains about $48 \%$ of all large public corporations, and more than three percent of all large private corporations. Therefore, the sample is particularly representative for large listed and non-listed public corporations.

A crucial element of our data set is detailed information on the firms' ownership structure. Ownership information is available for the years 1986-1996. Applying a concept of control, which is based on ultimate share ownership (Köke, 2000; see Appendix B), we identify whether a firm in any given year has a dominant controlling shareholder or not, and of which type this controlling shareholder is. In a second step, based on changes in the name of the so-defined ultimate owner we determine whether a change in control takes place. For the cases in which balance sheet data time series end before 1996 we determine whether this lack of balance sheet data is due to an acquisition or bankruptcy in the year ahead. In sum, we obtain information on the survival status (transfer of control, no transfer of control, or failure) for all sample firms. Since the last year for which the survival status can be calculated is 1996, and since the present analysis focuses on the year prior to a change in control or failure, the sample used for the analysis covers the years 1986-1995. 
In the data set, five types of ultimate owners can be identified: private, financial firms, non-financial firms, government authorities, and no single dominant shareholder (dispersed shares). Due to the limited number of cases we aggregate financial and non-financial shareholders as corporate shareholders. Appendix A contains a detailed description of the data sources and the procedure applied to construct the sample. Appendix B gives a technical description of the concept of control used to identify the ultimate owner of each sample firm. And Appendix $\mathrm{C}$ summarizes the definition of all variables used in this study.

The following Section 2.1 describes the frequency of changes in ownership and the frequency of the different types of shareholders either acting as a buyer or as a seller of sample firms. Section 2.2 provides some preliminary evidence on the determinants of control transfers and failure based on descriptive statistics.

\subsection{Frequency of control transfers and failure}

Table 2 shows that in most cases (91.9\% of firm years) neither a transfer of control nor firm failure occurs. For 38 firms ( $0.5 \%$ of firm years) we observe failure (defined as bankruptcy, insolvency, or voluntary liquidation). A change in control occurs in 576 cases $(7.6 \%$ of firm years). When a change in control takes place, a corporate shareholder is usually the new owner of the firm (61.3\%). A firm is less likely to be acquired by a private shareholder, and even less likely to be bought by a few large or many small shareholders (category dispersed). However, a firm is least likely to be sold to the government.

What is also evident from Table 2 is that the largest fraction of sample firms is ultimately owned by a corporate shareholder (50.2\%), a smaller fraction is owned by a private shareholder $(33.2 \%)$ or by the government $(5.3 \%)$. For $11.3 \%$ of all firm years there is no single dominant shareholder. As mentioned above, firms classified as 'dispersed' are owned either by a small number of similarly large shareholders or by a large number of very small shareholders. 
Overall, changes in ultimate ownership affect a significant number of sample firms. Out of 1,510 firms, 1,079 firms (71.5\%) do not experience any change in control during the 1986-1996 period. Vice versa, more than one quarter of all firms included in the sample experiences at least one change in ownership during the sample period. In about $21 \%$ of all firms the ultimate owner changes once, in about six percent twice, and in about one percent three or four times. But overall, several changes in control in the same firm are not very likely.

\section{$2.2 \quad$ Descriptive evidence}

Table 3 provides first evidence on the determinants of firm failure and transfers of control. It reports mean (columns 1-3) and median (columns 4-6) values of the variables that have been identified in Section 1 as potentially important determinants of changes in control and failure. These statistics are used to compare firms that experience a change in ownership or failure in the year ahead with firms that survive, i.e. do not experience a change in ownership and do not fail. For further descriptive evidence on the determinants of acquisition and failure using a larger variety of measures of firm-specific characteristics, see Köke (2001b).

Table 3 shows that failing firms and firms experiencing a change in control perform significantly worse than surviving firms not experiencing a change in control. In addition, performance of failing firms, measured as industry-adjusted return on assets, is worse than performance of acquired firms; this difference is significant at the one-percent level. An analogous relationship is found for financial pressure. Measured by the debt-to-assets ratio, financial pressure is significantly larger for firms that fail or experience a change in control, compared with surviving firms that do not experience any major change in ownership. In turn, financial pressure is larger for failing firms than for firms that are acquired (significant at the one-percent level).

Firm size provides another clear distinction between failing, surviving, and acquired firms. Firms that go bankrupt have, on average, total assets of about 660 million 
DM, and firms that are acquired have total assets of 960 million DM. Both figures are significantly below the respective figure for surviving firms, for which total assets amount to over 1,700 million DM. Similar differences are found for total sales and the number of employees as measures of firm size (not reported). Hence, firm size appears to reduce the likelihood of failure as well as a change in ownership.

Furthermore, ownership is significantly more concentrated in surviving firms, which do not experience a change in control, compared with failing firms and firms experiencing a change in control. For firms with a control change, this result holds irrespective whether ownership concentration is measured by the Herfindahl index, the size of the largest block, or a dummy variable indicating whether the respective firm has an ultimate owner according to our concept of control (see Appendix B) or not. However, failing and acquired firms are not significantly different in terms of ownership concentration. Furthermore, Table 3 indicates that a significantly larger fraction of firms survives when being part of a pyramid or being controlled by a cross-owned shareholder. In fact, none of the firms that declare bankruptcy is controlled by a shareholder that is part of the web of large German financial and non-financial conglomerates. The level of control, our measure of the height of the pyramid through which a firm is controlled, is significantly lower for firms that fail, compared with firms that survive and both, do or do not experience a change in control. In combination, the results on ownership structure suggest that complex ownership structures as reflected in large pyramids and cross-ownership appear to reduce the likelihood of firm failure, but not the likelihood of control transfers.

\section{Empirical models for control transfers and fai- lure}

The descriptive evidence discussed in Section 2.2 provides a first indication of the determinants of control transfers and firm failure. However, this evidence is only 
preliminary because the reported correlations do not imply any causal relationship. Therefore, we now analyze the issues related to transfers of corporate control and firm failure in a multivariate analysis, controlling for the fact that different variables can simultaneously affect the probability of acquisition or failure.

In Section 3.1, we first specify a multinomial logit (MNL) model for the three outcomes change (in ultimate ownership), failure, and no change (i.e. no change in ultimate ownership and no failure). In Section 3.2 we extend this basic model by interacting all explanatory variables with indicators for the types of owners. This allows for different effects of these variables depending on the type of owner, and thus for testing the hypotheses regarding the type of seller (Section 1.2). In Section 3.3, we refine the set of outcomes by subdividing the outcome change into four separate outcomes depending on the type of buyer. This extension of the basic MNL model allows for testing the hypotheses regarding the type of buyer (Section 1.3).

The MNL model is widely used in empirical studies because its globally concave likelihood function makes estimation straightforward. ${ }^{1}$ A drawback of this method is that it relies on relatively strong assumptions regarding the stochastic structure of the model. To address this concern, in Section 3.4 we test the robustness of the MNL results using a mixed multinomial logit model (MMNL), which is much more flexible in comparison with the MNL model. As it turns out, the additional assumptions of the MNL model are rejected, but the findings from the MNL model remain qualitatively unchanged.

In all regressions, we use one-year-lagged values of firm-specific characteristics as explanatory variables. These characteristics include the measures of performance, financial pressure, firm size, and ownership structure described in the previous section. The selection of these variables is based on an extensive descriptive analysis of which variables are useful to explain acquisition and failure (Köke, 2001b). Nevertheless, in Section 3.5 we check whether our findings are sensitive to the use of alternative measures of the selected firm-specific characteristics. ${ }^{2}$ 


\subsection{Determinants of control transfers and firm failure}

In a first step, we examine the impact of firm performance, financial pressure, and other firm-specific characteristics on ownership change and failure in a simple multinomial logit model (MNL). For the moment, we ignore the different types of owners. In this model, there are three possible outcomes: change (in ultimate owner), failure, and no change.

Table 4 shows the results of two specifications. In Model (1), the outcome probabilities are modeled to depend on the lagged values of the firm characteristics only, ignoring the ownership types altogether. As the reference outcome relative to which the coefficients will be interpreted, we choose the outcome no change because this outcome is the most frequent. For example, the significantly negative parameter estimate for performance (measured as industry-adjusted return on assets) in the column change implies that the probability of a control transfer instead of no change in control falls with rising performance.

We find a significantly negative impact of performance on the likelihood of acquisition and failure. Hence, a test of the null hypothesis that Hypothesis C1 is incorrect is statistically rejected. Poor performance appears to make a change in control as well as firm failure more likely. The effect of performance on failure is significantly more pronounced than its effect on change. Our finding on the effect of performance for acquisition and failure is consistent with evidence from the US (Powell, 1997; Denis and Sarin, 1999; Astebro and Winter, 2001, Maksimovic and Phillips, 2001). The results in Table 4 also support Hypothesis C2: Firms with high financial pressure, here reflected in a high debt-to-assets ratio, have a larger probability to experience a change in control, and an even larger probability to fail.

Hypothesis C3 predicts a nonlinear impact of ownership concentration on the likelihood of a control transfer. We find support for this hypothesis. To test for a non-linear impact of ownership concentration, the model includes a second-order polynomial of the Herfindahl index. For the change outcome, the estimated poly- 
nomial has a negative first derivative in the domain of the Herfindahl index which is, by definition, bounded between zero and one. This finding is consistent with Holmström and Tirole (1993) who argue that the probability of a takeover should decrease with increasing ownership concentration. We will come back to this finding in Section 3.2, where it will turn out that this effect depends on the previous control status. Concerning the probability of failure, the results indicate a negative impact of ownership concentration for concentration levels that are typical for German firms (Köke, 2001a). However, this effect is statistically insignificant.

Firms that are part of a pyramid or controlled by a cross-owned shareholder are less likely to experience a change in control, as Hypothesis $\mathbf{C 4}$ predicts, but this effect is not or only weakly significant. However, we find that the higher is the level in a pyramid at which the ultimate shareholder is located, the higher is the probability for a transfer of control. One interpretation of this effect could be that due to information asymmetries monitoring becomes increasingly difficult with higher pyramid structure, potentially implying greater organizational inefficiency. This would explain why pyramids tend to sell firms that operate on their (organizational) periphery. ${ }^{3}$ Concerning failure, we cannot find any significant impact of pyramids on the probability of failure. Since no firm with cross-owned shareholders failed in our sample, no finite coefficient for failure can be identified.

Finally, Hypothesis C5 is strongly supported. Taking the natural logarithm of total assets as a measure of firm size, a change in control as well as a failure is less likely to occur for large firms. This confirms that firm size works as a kind of takeover deterrent (Bethel et al., 1998; Mulherin and Boone, 2000), but also as a shelter against failure.

Table 4 also shows the results of another model that we call Model (2). It is equivalent to Model (1) except that we add indicator variables for the type of owner. We find that private owners tend to sell their blocks less frequently compared with corporate owners. A likelihood ratio test shows that these indicators cannot be ignored. Thus, taking into account different types of owners is important. Note 
that the other parameter estimates hardly change; one exception is the indicator for cross ownership, for which the coefficient becomes more pronounced. Given the estimates for the ownership type indicators, this new result for cross-ownership was to be expected because cross-held firms are, by definition, controlled by firms. So the coefficient for cross-ownership in Model (1) partly picks up the effect of the ownership type. Since corporate owners sell their controlling share blocks more frequently than private owners, this leads to a bias of the parameter estimate in Model (1) which is removed in Model (2).

\subsection{The type of seller in control transfers}

In the previous section, different types of owners were accounted for by including identity indicators into the specification of Model (2). In this section, we also take into account different types of owners, but now we examine whether the impact of explanatory variables varies depending on the type of seller, as suggested in Section 1.2. For example, due to wealth constraints particularly private blockholders should be less able to provide extra capital to a firm in financial difficulties, and in turn be more likely to sell this firm. Therefore, we expect the parameter associated with the impact of financial pressure on the change probability to be larger when the firm is owned by a private shareholder, compared with a firm that is owned by a corporate shareholder. Controlling for the type of owner is also important from the methodological point of view. If the outcome probabilities differ by type of owner, ignoring these effects leads to biased parameter estimates unless the explanatory variables do not systematically differ across shareholder types. This can be seen as a classical omitted variables problem.

We therefore extend our model by allowing the parameters to vary by the type of seller, i.e. by the type of owner before an eventual control transaction takes place. Each explanatory variable is fully interacted with indicator variables for each of the following shareholder types: private, corporate, government, and dispersed; see also 
Section 2.1. In this way we allow for and can test the hypotheses formulated in Section 1.2.

Table 5 shows the results of this fully interacted model. It is to be read as follows: The last column shows the parameter estimates for failure relative to no change as before in Table 4. The first column presents the parameter estimates for change relative to no change, not interacted with the indicators for the type of owner. In the following three columns, estimates for the interaction terms with the indicators for dispersed ownership, control by a private shareholder, and control by the government are shown. That is, control by a corporate shareholder is the reference ownership type for the probability of a control transfer. The impact of a firm characteristic on the probability of a control transfer can therefore be directly seen in the first column if the firm is controlled by a corporate shareholder. For the firms with other types of owners, the impact is obtained by adding the coefficient in the respective column to the coefficient in the first column.

Regarding failure, all results from Section 3.1 remain qualitatively unchanged; therefore, we do not comment on them further. In contrast, regarding a change in control we find some important differences compared to the models in Table 4, where the type of owner is not interacted with firm-specific characteristics. In particular, we find that the impact of performance on the probability of a control transfer does not significantly differ across ownership types; the parameter estimates in columns two to four of Table 5 are insignificant. Hence, we do not find empirical support for Hypothesis S1 that shareholders differ in their reaction to poor performance. However, we find support for Hypothesis S2 that shareholders react differently to financial pressure. The effect of financial pressure is not statistically different from zero for firms under control of a corporate shareholder. This is consistent with the notion that corporate shareholders have access to internal capital markets which can be used for cash transfers within conglomerates (Lamont, 1997). In contrast, firms appear to be more likely to be sold when being under control of a private owner. This supports the notion of liquidity constraints which should be particularly relevant for 
private investors. In turn, firms with dispersed ownership as well as firms under control of the government are not statistically different from firms under control of a corporate shareholder in their reaction to financial pressure.

A closer look at the estimated effects of ownership concentration provides some interesting insights. Hypothesis C3 predicts a non-linear impact of ownership concentration on trades of control blocks, or more precisely, a positive impact for low concentration and a negative impact for high concentration. Figure 1 helps to interpret the estimated polynomial. For different shareholder types (dispersed, private, corporate) it shows the predicted probability that a firm will experience a change in control, given its actual characteristics for different hypothetical values of the Herfindahl index, our measure of share concentration. Figure 1 shows these probabilities, averaged over all firms observed for the three types of controlling shareholders. The lines are drawn for the values of the Herfindahl index between the $10^{\text {th }}$ and the $90^{\text {th }}$ percentile of the firms in these groups.

There are two major results that can be learned from Figure 1. First, the effect of ownership concentration is strong. Compared to a firm with a fully dispersed ownership structure (Herfindahl is approximately zero), a firm with four equally large shareholders (Herfindahl index is 0.25 ) is almost twice as likely to experience a change in ownership. Second, the estimated shape of the curve for dispersed ownership differs from the shape for firms under tight control. While the former has the shape as predicted in Hypothesis C3, the latter ones have a negative slope for all values of the Herfindahl index, and the second order term leads to a minimum probability roughly at maximum concentration (Herfindahl index is one). Ownership concentration apparently has different impacts on these two groups of firms. We argue that different effects of ownership concentration depending on the tightness of control are reasonable. The positive impact predicted for very low concentration and observed for dispersed shares can be due to the free-riding behavior of very small shareholders which may prevent takeovers (Grossman and Hart, 1980). As concentration increases while firms remain under the influence of several large minority 
shareholders, the agency problem persists since management is not subject to tight control of one dominant shareholder. At the same time, the costs associated with block purchases should shrink as it becomes easier for a potential buyer to contact all major shareholders. For firms under tight control of only one large shareholder, communication costs should be the lowest because there is a single counter party to make the deal with (Burkart et al., 2000). But further increasing ownership concentration reduces the firm's stock market liquidity, as argued by Holmström and Tirole (1993). This effect overcompensates the effect of decreasing communication costs and altogether makes a control transfer less likely.

\subsection{The type of buyer in control transfers}

As argued in Section 1.3, the type of the buyer could also play an important role in control transactions. To address this issue we split the outcome change into four outcomes: change to dispersed ownership, change to private owner, change to corporate owner, and change to government. The purpose of this model is to test whether some firm-specific characteristics vary in their impact on the probability of a change in control, depending on the type buyer.

Regarding failure, again all results from Section 3.1 remain qualitatively unchanged; therefore, we do not comment on them further. Regarding control transfers, similar to the evidence on the type of seller, as discussed in Section 3.2, we find that the type of buyer should not be ignored when investigating the determinants of control transfers and failure. In particular, we find that the performance coefficients are not statistically different from zero for firms under private, corporate, or dispersed ownership; only the coefficients for failure and change to government are significantly negative (Table 6). These results imply that poorly performing firms are more likely to be sold to the government, and that they are also more likely to fail. But there is no evidence that corporate shareholders are somehow more likely than other types of shareholders to buy a poorly performing firm. Hence, there is no empirical support for Hypothesis B1. 
Table 6 also shows that firms with a large burden of debt are more likely to be sold to a corporate shareholder, and that they are also more likely to fail (compared with the reference outcome of no change). The respective coefficients for other types of shareholders are also positive but insignificant. An additional Wald test shows, however, that the difference between the coefficients for all types of shareholders is statistically zero. Therefore, there is also no evidence supporting Hypothesis B2.

In contrast, we find strong support for Hypothesis B3 that the impact of firm size on the probability of a control transfer differs, depending on the type of buyer. Large firms are less likely to be purchased by private as well as corporate shareholders. The impact of firm size is most pronounced for private shareholders, whose coefficient is higher in absolute terms than the coefficient for corporate shareholders. ${ }^{4}$ When a firm is bought by the government or sold to the public (dispersed ownership), firm size apparently does not matter. These findings are broadly consistent with evidence provided by Bethel et al. (1998) and Mulherin and Boone (2000) who report for the US that firm size reduces the likelihood of an acquisition. However, we find that for the sale of German corporations this type of liquidity constraint applies only to private and corporate buyers, not to the government.

As a check of robustness, we also estimated a model that includes different types of buyers and different types of sellers simultaneously. The total number of 92 coefficients to be estimated reduces the degrees of freedom noticeably. We find that the main results as presented in this and the previous section remain unchanged; see Tables 7 and 8 .

\subsection{A more flexible econometric model}

In the previous sections, we based our estimates on the multinomial logit (MNL) model. The computational simplicity of the MNL model comes at costs since it imposes strong restrictions on the stochastic structure. To check whether our results are sensitive to these restrictions, we estimate a mixed multinomial logit (MMNL) model. 
This econometric approach generalizes the MNL model and is much more flexible. In contrast to the simple MNL model, it allows for contemporaneous correlations of the probabilities for different outcomes as well as for intertemporal correlations emerging from unobserved firm-specific heterogeneity in panel data.

In general, the probability that for firm $n$ at time $t$ the outcome $i$ is realized is modeled as

$$
P_{n t}^{i}=\int \frac{e^{\mathbf{x}_{n t^{\prime}} \boldsymbol{\beta}^{i}+\mathbf{z}^{i^{\prime}} \boldsymbol{\gamma}_{n t}}}{\sum_{j \in \mathcal{C}} e^{\mathbf{x}_{n t^{\prime}} \boldsymbol{\beta}^{j}+\mathbf{z}^{j^{\prime}} \boldsymbol{\gamma}_{n t}}} f\left(\boldsymbol{\gamma}_{n t} \mid \boldsymbol{\theta}\right) d \boldsymbol{\gamma}_{n t} .
$$

The vector $\mathbf{x}_{n t}$ contains the firm-specific explanatory variables and the vector $\boldsymbol{\beta}^{i}$ the associated outcome-specific parameters as in the simple MNL model. Additionally, the term $\mathbf{z}^{i^{\prime}} \gamma_{n}$ is included in the MMNL specification. In our application, $\mathbf{z}^{i}$ contains indicator variables for the outcomes as will be discussed below. The vector $\gamma_{n t}$ contains random variables. In this application, they are assumed to be normally distributed with zero means and covariances as well as unknown variances, which are collected in the vector $\boldsymbol{\theta}$.

We specify two different kinds of these additional random terms:

- Some of the $\gamma_{n t}$ are specified to be independently distributed both over firms and over time. The associated indicator variables in $\mathbf{z}^{i}$ let these random variables enter more than one alternative. They constitute random shocks that jointly make these outcomes more or less likely and generate correlations of these events. As a result, the IIA assumption of the MNL model is relaxed.

- Other elements of $\gamma_{n t}$ are assumed to be independently distributed over firms but constant over time for each firm. They constitute firm-specific random effects and generate the correlations of the outcome probabilities over time that are typical for panel data models.

In this way we specify a substantially more flexible econometric model than the MNL. In general, the MMNL approach allows the weights $\mathbf{z}^{i}$ of the random variables 
to vary by decision maker and time, too. McFadden and Train (2000) show that the choice probabilities generated by any random utility maximization model can be approximated arbitrarily closely by a MMNL model. The MMNL model has been successfully used in different applied studies; see for example Brownstone and Train (1999). Because of the multi-dimensional integral in equation (1), there is no closedform solution for the log likelihood function. We estimate this model by the method of maximum simulated likelihood (MSL). ${ }^{5}$

Table 9 compares Model (1), which was presented in Table 4, with a corresponding MMNL model. In this model, we include unobserved heterogeneity of control transfers and a correlation between the outcomes change and fail. The intuition for a correlation between these two outcomes is that to a certain extent both alternatives can be regarded as substitutes, for example in times of financial distress. We find that in the MMNL model both added parameters are significantly different from zero. Note that the MNL model constrains them to be equal to zero. In addition, we conduct a likelihood ratio test on the null hypothesis of the validity of the MNL model: It rejects the MNL in favor of the MMNL model. Despite these findings, the estimates for all other parameters are not qualitatively different between the two models. Therefore, the results obtained above using the MNL model appear not to be sensitive to the inclusion of unobserved heterogeneity or correlations between the alternatives.

Furthermore, we estimate a MMNL model for the type of buyers, corresponding to Model (4). The specification of the contemporaneous correlation structure resembles the structure of a multi-level nested logit model, which is depicted in Figure 2. The outcomes change and fail are allowed to be similar to each other. This is reflected in a common node. The different change to ... outcomes are allowed to be even more similar to each other; therefore, they share a further node. Finally, the outcomes change to a private owner, change to a corporate owner, and change to the government are also allowed to be similar to each other because they all involve the presence of a dominant owner after the change in control. A third node reflects 
this situation graphically.

The results of this model are shown in Table 10. Again, the MNL model is clearly rejected, indicating unobserved heterogeneity as well as correlations between the outcomes. Nevertheless, again we find that the estimated parameters are not qualitatively different between this MMNL model and the MNL model in Table 6, which examines the type of buyer. We conclude that our empirical findings from Sections 3.1-3.3 are generally not sensitive to different econometric specifications.

\subsection{Other sensitivity checks}

To check whether our results are sensitive to the chosen measures of performance and financial pressure, we perform a number of estimations in which we additionally include alternative measures for these firm characteristics. Table 11 shows the results for the basic MNL model with alternative measures of performance. Model (1) is the MNL model shown in Table 4, which has been discussed in Section 3.1. In Models (1a) through (1c), we add the following performance measures: total factor productivity, annual stock market return, and cash flow on equity. Similar to return on assets (ROA), these measures are industry-adjusted in the sense that they measure the difference to median industry performance (two-digit industry level). Only stock market return is market-adjusted in the sense that it is corrected for the return of the DAFOX, the size-weighted return of all German stocks. The three new performance measures have missing values for some of the observations. Therefore, sample size decreases when adding these alternative measures. For stock market return this is obvious because it can be calculated only for listed firms.

Table 11 shows that none of the additional coefficients is statistically different from zero, and a test of the hypothesis that they are jointly zero cannot be rejected; for the test statistic, see the last row. Note that the other coefficients hardly change when a new performance variable is included. We infer from this robustness test that return on assets, which we include in all regressions, picks up all relevant 
information regarding performance. Therefore we are confident that its inclusion in the regressions suffices, and that we can ignore the other performance variables. If they do not contain any additional information, they will only lead to inefficient estimates.

We proceed analogously for different measures of financial pressure. The results of these estimates are shown in Table 12 . We find that only the current ratio, a measure of liquidity, has a weakly significant coefficient. But its influence is small, and the other parameters do not change qualitatively when the current ratio is included. Note that we loose roughly ten percent of observations due to missing information when the current ratio is included in the specification. This leads to inefficiencies and, if the firms we must drop differ systematically from the remaining firms, also to sample selection bias. Hence, we decide not to include this variable in our analysis. As argued before, this decision does not seem to influence our main findings.

Finally, firm-specific characteristics such as performance could be affected in the year when a change in control takes place. If this is the case, then our explanatory variables could be systematically different from their normal values, and hence should at least be questionable as determinants of an acquisition or a failure that takes place in the following year. To check whether our results are affected by this problem, we re-estimate Model (1) from Section 3.1 excluding all firm years in which a change in control takes place. We find essentially the same results. Only the secondorder term of the Herfindahl index looses its significance, and the pyramid dummy becomes significantly negative at the five-percent level.

\section{Conclusions}

This study provides an improved understanding of the dynamics of corporate ownership and firm survival in Germany. In particular, we consider the role of different types of shareholders as sellers and buyers of control blocks. The empirical analysis 
is based on a sample of over 1,500 large and medium-sized German corporations for the years 1986-1995.

There are two major findings. First, poor performance and high financial pressure make firms more likely to fail and to experience a change in ownership. This latter finding contrasts with the widespread belief that acquisitions target well-performing firms to the disadvantage of shareholders and other stakeholders. It also stands in contrast to Franks and Mayer (2001) who argue that block sales in Germany are not disciplinary in nature. Using a panel of 75 firms in a bivariate analysis, they cannot find that block sales increase management turnover particularly for poorly performing firms. But our finding is consistent with the view that acquisitions can have a disciplining effect on poorly performing firms (Denis and Sarin, 1999; Maksimovic and Phillips, 2001). Our second major finding is that both the type of seller and the type of buyer matter in transfers of corporate control. This implies that not taking into account different shareholder types in control transactions can bias estimation results. This is a classical omitted variables problem. Börsch-Supan and Köke (2000) discuss this and other common methodological problems in corporate governance studies in detail.

For illustration, take the example of ownership concentration. We find that concentration reduces the likelihood of a change in ownership when we do not control for the type of seller. Controlling for the type of seller, we find that (1) this effect is not monotonous but rather non-linear in the degree of ownership concentration, and that (2) this non-linearity depends on whether a firm is initially under tight or under loose control of shareholders. More precisely, for firms with a highly dispersed ownership structure the probability of a change in ownership increases with share concentration, but it decreases when concentration exceeds a particular level. Firms with three or four equally large shareholders are most likely to be acquired. One interpretation for the positive impact of concentration on the likelihood of a change in control is that free-riding of small shareholders increases the costs of a change in control, and therefore makes a control change less likely. Vice versa, when con- 
centration becomes too large, capital markets might not be able to determine the necessity of an acquisition any longer (Holmström and Tirole, 1993). This implies a lower probability of a change in control for firms without a sufficiently dispersed ownership structure. In combination, our findings stress the importance of the existing share concentration in negotiations over corporate control transactions. Burkart et al. (2000) provide important theoretical work in this direction.

The other findings of this study can be summarized as follows: Irrespective of the type of the controlling shareholder, firms are more likely to fail and to experience a change in ownership when financial pressure is high and firm size is small. This is consistent with previous studies (see, e.g., Altman, 1968; Bethel et al., 1998; Zingales, 1998). In contrast, complex ownership structures, reflected for example in cross-ownership, reduce the likelihood for a change in control. This is consistent with theoretical predictions (Bebchuk et al., 2000). Concerning the type of seller, private owners are more likely to sell a firm when financial pressure increases, but corporate shareholders are not. This is consistent with evidence that corporate owners have access to internal capital markets (Lamont, 1997), and that private owners face some liquidity constraints. Regarding the buyers of control blocks, large firms are less likely to be sold to a corporate shareholder than to the government, and they are even less likely to be sold to a private shareholder. Again, the latter finding suggests that private owners are liquidity-constrained. Interestingly, firms under control of cross-owned shareholders, which are by definition corporate shareholders, are more likely to be sold to the public or the government, but less likely to be sold to another corporate investor. This indicates that, if complex ownership structures are dissolved, then this is done either by spreading shares widely or by selling control blocks to the government.

Our findings have policy implications. The finding that poorly performing firms are more likely to be acquired is consistent with the notion that acquisitions can play an important governance role. At the same time, we find that firms with complex ownership structures, reflected for example in cross-ownership, are less likely 
to experience an acquisition. This indicates that ownership complexity acts as a takeover deterrent. In combination, these results suggest that a policy attempting to reduce ownership complexity could make the market for corporate control more active. In turn, tighter managerial control by market forces could enhance the efficiency of corporate governance. Currently, in most European countries dissolving complex ownership structures is costly because capital gains from sales of corporate assets are subject to the regular corporate tax. Lang et al. (2001) argue that this tax increases the transaction costs associated with block trades, and therefore acts as a barrier to efficient allocation of ownership and investment. Recognizing the benefits of a more active market for corporate control, Germany has abolished this tax on capital gains, starting January 2002. When this part of the tax reform proves to reduce the transaction costs associated with block trades and to support structural change, it might be recommendable for other continental European countries where corporate ownership is often complex as well (La Porta et al., 1999).

A potential problem of our approach might be that some of our regressors are endogenous, in particular performance. Since we use lagged values of our explanatory variables, the potential sources of endogeneity are not changes in performance during or after takeovers. Neither does our study suffer from a direct link between ownership types and performance, which is examined for example by Brickley et al. (1988) who regress performance on ownership types. But if the market for corporate control indeed works as a disciplinary device (Jensen, 1988), already the threat of an acquisition should increase firm performance. This creates a positive causal relationship between the probability of a change in control and firm performance, and therefore might lead to coefficient estimates that do not represent the causal effect of performance on the probability of a control change. As this discussion shows, one would expect the estimates to be biased downwards in absolute value by this endogeneity. Therefore, our estimates of the coefficients for performance can be interpreted as a lower bound for the causal effect on the control change probability. An econometric approach that jointly models the endogeneity of control transfers and firm 
performance could give further insights about the causal interdependence of these important variables. Finally, our approach of taking into account differences between shareholder types could be extended to model the effects that different shareholder types have on corporate governance and efficiency. Evidence on this issue is particularly important as one group of shareholders, the institutional investors, is steadily gaining influence on corporate policy (see, e.g., Smith, 1996). But this is beyond the scope of this paper and will be left for future research. 


\section{A Data sources and sample selection}

The first main pillar of data comes from Hoppenstedt's Balance Sheet Database (BSD). An important feature of this data source is that it contains information on listed and non-listed incorporated firms, both for public (AG) and private corporations $(\mathrm{GmbH})$. We take 1986 as the starting year because a change in disclosure rules hinders comparability of the annual reports before and after the year $1986 .{ }^{6}$ The last year of our investigation is 1996 because our series of ownership data ends in this year. For the period 1986-1996, BSD contains 5,679 firms (31,294 firm years) for which consolidated balance sheet data are available. We eliminate firms from the utility, traffic, and telecommunications industries because they were still predominantly government-owned during the period of observation. As a matter of comparability, we also eliminate firms which primarily operate in the banking and insurance business, while operating little in non-financial activities. In combination, selection by industry causes 1,928 firm deletions.

The second main pillar-data on ownership structures-is obtained from annual reports published by former Bayerische Hypotheken- und Wechsel-Bank (in short, Hypobank). These reports contain information on direct ownership of common stock (Stammaktien) for all listed German firms. In addition, Hypobank provides information on direct ownership of common stock for large non-listed firms (Stammaktien for the non-listed AG and Gesellschafteranteile for the GmbH which cannot be listed). Hypobank reports the size and the name of a direct owner when the size of the ownership block exceeds five percent. In general, ownership rights as reported by Hypobank correspond to voting rights (see Köke, 2000).

Ownership information from Hypobank cannot readily be used in our analysis for three reasons. First, ownership information from Hypobank only refers to the $d i$ rect level of owners. But the present analysis requires to identify the ultimate owner of each sample firm (see Appendix B). Second, Hypobank does not directly reveal ownership information on medium-sized non-listed firms. Other commercial data 
sources are also of little help because during our period of observation, non-listed firms generally have not been subject to strictly enforced disclosure requirements. Therefore, we construct the relevant ownership structures by searching the information on investments in subsidiaries and affiliated companies which is given in the appendix to each company in Hypobank. In addition, we search the Mannheim Company Database (MUP) located at the ZEW in Mannheim. Thereby we obtain ownership structures on many medium-sized non-listed firms, mainly for private corporations $(\mathrm{GmbH})$. Third, some firms changed their names during the period of observation, for example following takeovers or restructuring of conglomerates. Since changes in ownership are crucial to the data collection procedure, we adjust for name changes and obtain a panel on ownership structures through the years 1986-1996.

Furthermore, we drop firms with less than two consecutive years for which ownership information is available because our analysis requires to calculate changes in ownership (2,216 firm deletions). Since our analysis focuses on the year prior to the year in which a change in ownership or firm failure occurs, we exclude firm-years for which no ownership data in the following year are available. For most firms this is the year 1996, the final year of the sample. Finally, 25 firms must be eliminated due to missing values on the variables used in the empirical analysis. This selection procedure leaves 1,510 firms (7,577 firm years) for the years 1986-1995. Table 13 summarizes the selection procedure.

\section{B Concept of control}

Large German corporations typically show complex ownership structures such as pyramids with several layers of ownership and cross-ownership between firms (La Porta et al., 1999; Böhmer, 2000; Köke, 2001a). For Germany such analysis of direct ownership is therefore not sufficient. By using the concept of ultimate ownership it becomes possible to define corporate control within complex ownership structures. 
This requires the analysis of control chains throughout several levels and the identification of a most powerful ultimate owner if any such exists. We use the concept of ultimate ownership in this study.

The identification of the ultimate owner for each firm is based upon German corporate law and involves two steps. First, we identify the ultimate owner for each direct shareholder using the following three rules. Rule 1 (strong ownership rule): A chain of control is pursued to the next level if the shareholder being analyzed is owned to $50 \%$ or more by a shareholder on the next level, while all other shareholders on the next level own less than 50\%. Rule 2 (weak ownership rule): If rule 1 does not apply, a chain of control is pursued to the next level if the shareholder being analyzed is owned to $25 \%$ or more by a shareholder on the next level, while all other shareholders on the next level own less than 25\%. Rule 3 (stop rule): If neither rule 1 nor rule 2 applies, a chain of control is not pursued further. These rules guarantee that no more than one ultimate owner is identified for each direct shareholder. Note that if a shareholder has split his ownership stake in a particular company into several smaller stakes, for example into two blocks of $50 \%$ held by two subsidiary firms, we combine these smaller stakes into one single block. We set the first cut-off point at $50 \%$ because German law allows an investor owning $50 \%$ of all shares to appoint management. ${ }^{7}$ The second cut-off point is set at $25 \%$ because an investor owning $25 \%$ of the shares has the right to veto decisions. In a second step in determining the ultimate owner for each sample firm, we apply the three rules to all direct shareholders. This allows us to identify one single shareholder that is in ultimate control. When no single shareholder fulfills the criteria, this firm is seen to have no ultimate owner.

\section{Definition of variables}

The definition of all variables used in this study can be found in Table 14 . 


\section{Notes}

${ }^{1}$ See Greene (1997, p. 920) for a textbook presentation of the MNL model.

${ }^{2}$ For the definition of all variables employed, see Appendix C.

${ }^{3} \mathrm{An}$ alternative interpretation could be that longer control chains in pyramids automatically increase the likelihood that one of the chain firms experiences a change in ultimate ownership. In consequence, the likelihood of a control transfer for a sample firm would increase when this firm is low in a pyramid. However, if the dummies for pyramids and cross-ownership have any additional impact besides the impact of the height of a pyramid (as shown in our second specification in Table 4), these effects would be robust against this critique.

${ }^{4} \mathrm{~A}$ Wald test shows that the difference between both coefficients is significant at the ten-percent level.

${ }^{5}$ See Hajivassiliou and Ruud (1994). We benefitted greatly from the GAUSS code for the MSL estimation of mixed logit models provided by Kenneth Train.

${ }^{6}$ In 1985 several changes were introduced in German corporate law ( $\$ 289$ HGB), most of them triggered by the European Community's Fourth Company Law Directive on the harmonization of national requirements pertaining to financial statements.

${ }^{7} \mathrm{~A} 50 \%$ majority is sufficient to dismiss management after their regular period of office. But a majority of $75 \%$ is required to dismiss management during its period of office ( $\$ 103$ (1) AktG). 


\section{References}

Adams, M., 1994, "Die Usurpation von Aktionärsbefugnissen mittels Ringverpflechtung in der Deutschland AG," Die Aktiengesellschaft, 4, 148-158.

Altman, E., 1968, "Financial Ratios, Discriminant Analysis, and the Prediction of Corporate Bankruptcy," Journal of Finance, 23, 589-609.

Astebro, T. and J. Winter, 2001, "More Than a Dummy: The Probability of Survival, Failure, and Acquisition of Firms in Financial Distress," working paper, University of Waterloo and University of Mannheim.

Barcley, M.J. and C.G. Holderness, 1991, "Negotiated Block Trades and Corporate Control," Journal of Finance, 46, 861-78.

Bebchuk, L.A., 1994, "Efficient and Inefficient Sales of Corporate Control," Quarterly Journal of Economics, 109, 957-993.

Bebchuk, L.A., R. Kraakman, and G. Triantis, 2000, "Stock Pyramids, CrossOwnership, and Dual Class Equity," in: R.K. Morck (ed.), Concentrated Corporate Ownership, Chicago, 295-315.

Berger, P.G. and E. Ofek, 1999, "Causes and Consequences of Corporate Refocusing Programs," Review of Financial Studies, 12 (2), 311-345.

Bethel, J.E., J.P. Liebeskind, and T. Opler, 1998, "Block Share Purchases and Corporate Performance," Journal of Finance, 53 (2), 605-634.

Böhmer, E., 2000, "Industry Groups, Bank Control, and Large Shareholders: An Analysis of German Takeovers," Journal of Financial Intermediation, 9 (2), $117-148$.

Börsch-Supan, A. and J. Köke, 2000, "An Applied Econometricians' View of Empirical Corporate Governance Studies," ZEW Discussion Paper 00-17, Centre for European Economic Research, Mannheim. 
Brickley, J.A., R.C. Lease, and C.W. Smith, Jr., 1988, "Ownership Structure and Voting on Antitakeover Amendments," Journal of Financial Economics, 20, 267-291.

Brownstone, D. and K. Train, 1999, "Forecasting New Product Penetration With Flexible Substitution Patterns," Journal of Econometrics, 89, 109-129.

Burkart, M., D. Gromb, and F. Panunzi, 2000, "Agency Conflicts in Public and Negotiated Transfers of Corporate Control," Journal of Finance, 55 (2), 647677.

Denis, D.J. and A. Sarin, 1999, "Ownership and Board Structures in Publicly Traded Corporations," Journal of Financial Economics, 52, 187-223.

Denis, D.J. and T.A. Kruse, 2000, "Managerial Discipline and Corporate Restructuring Following Performance Declines," Journal of Financial Economics, 55, $391-424$.

Franks, J. and C. Mayer, 1995, "Ownership and Control," in: H. Siebert (ed.), Trends in Business Organization, Mohr, Tübingen, 171-200.

Franks, J. and C. Mayer, 1998, "Bank Control, Takeovers and Corporate Governance in Germany," Journal of Banking and Finance, 22, 1385-1403.

Franks, J., C. Mayer, and L. Renneboog, 1999, "Who Disciplines Bad Management?," working paper, Oxford Financial Research Centre, Oxford.

Franks, J. and C. Mayer, 2001, "Ownership and Control of German Corporations," Review of Financial Studies, 14, 943-977.

Greene, W.H., 1997, Econometric Analysis, Prentice Hall, Upper Saddle River.

Grossman, S.J. and O.D. Hart, 1980, "Takeover Bids, the Free-Rider Problem, and the Theory of the Corporation," Bell Journal of Economics, 11, 42-64. 
Hajivassiliou, V.A. and P.A. Ruud, 1994, "Classical Estimation Methods for LDV Models Using Simulation," in: R.F. Engle and D.L. McFadden (eds.), Handbook of Econometrics Vol. IV, Elsevier, Amsterdam, 2383-2441.

Holmström, B. and J. Tirole, 1993, "Market Liquidity and Performance Monitoring," Journal of Political Economy, 101 (4), 679-709.

Jenkinson, T. and A. Ljungqvist, 2001, "Hostile Stakes and the Role of Banks in German Corporate Governance," Journal of Corporate Finance, 7 (4), 447474.

Jensen, M.C., 1986, "Agency Costs of Free Cash Flow, Corporate Finance and Takeovers," American Economic Review, 76, 323-329.

Jensen, M.C., 1988, "Takeovers: Their Causes and Consequences," Journal of Economic Perspectives, 2, 21-48.

Kahan, M., 1993, "Sales of Corporate Control," Journal of Law, Economics, and Organization, 9, 368-379.

Köke, J., 2000, "Control Transfers in Corporate Germany: Their Frequency, Causes, and Consequences," ZEW Discussion Paper 00-67, Centre for European Economic Research, Mannheim.

Köke, J., 2001a, "New Evidence on Ownership Structures in Germany," Kredit und Kapital, 34 (2), 257-292.

Köke, J., 2001b, "Survival, Acquisition, and Failure in Corporate Germany: Lessons for Empirical Studies," ZEW Discussion Paper 01-30, Centre for European Economic Research, Mannheim.

Kole, S. and K. Lehn, 1999, "Deregulation and the Adaptation of Governance Structure: The Case of the US Airline Industry," Journal of Financial Economics, $52,79-117$. 
Lamont, O., 1997, "Cash Flow and Investment: Evidence from Internal Capital Markets," Journal of Finance, 52, 83-110.

Lang, M.H., E.L. Maydew, and D.A. Shackelford, 2001, "Bringing Down the Other Berlin Wall: Germany's Repeal of the Corporate Capital Gains Tax," working paper, University of North Carolina.

La Porta, R., F. Lopez-de-Silanes, and A. Shleifer, 1999, "Corporate Ownership Around the World," Journal of Finance, 54 (2), 471-517.

Maksimovic, V. and G. Phillips, 2001, "The Market for Corporate Assets: Who Engages in Mergers and Asset Sales and Are There Efficiency Gains?," Journal of Finance, 56 (6), 2019-2065.

McFadden, D. and K. Train, 2000, "Mixed MNL Models for Discrete Response," Journal of Applied Econometrics, 15, 447-470.

Mitchell, M.L. and J.H. Mulherin, 1996, "The Impact of Industry Shocks on Takeover and Restructuring Activity," Journal of Financial Economics, 41, 193-229.

Mulherin, J.H. and A.L. Boone, 2000, "Comparing Acquisitions and Divestitures," Journal of Corporate Finance, 6, 117-139.

Pagano, M. and A. Röell, 1996, "The Choice of Stock Ownership Structure: Agency Costs, Monitoring, and the Decision To Go Public," in: M. Pagano and A. Röell (eds.), The Decision to Go Public and the Stock Market, Tipor, Rom, 41-75.

Powell, R.G., 1997, "Modelling Takeover Likelihood," Journal of Business Finance and Accounting, 24, 1009-1030.

Renneboog, L., 2000, "Ownership, Managerial Control and the Governance of Companies Listed on the Brussels Stock Exchange," Journal of Banking and Finance, 24 (12), 1959-1995.

Shleifer, A. and R.W. Vishny, 1986, "Large Shareholders and Corporate Control," Journal of Political Economy, 94 (3), 461-488. 
Shleifer, A. and R.W. Vishny, 1992, "Liquidation Values and Debt Capacity: A Market Equilibrium Approach," Journal of Finance, 47, 1343-1366.

Smith, M.P., 1996, "Shareholder Activism by Institutional Investors: Evidence from CalPERS," Journal of Finance, 51 (1), 227-252.

Wenger, E., and Kaserer, C., 1998, "The German System of Corporate Governance: A Model Which Should Not Be Imitated," in: S.W. Black and M. Moersch (eds.), Competition and Convergence in Financial Markets, Elsevier, Amsterdam, 41-78.

Zingales, L., 1998, "Survival of the Fittest or the Fattest? Exit and Financing in the Trucking Industry," Journal of Finance, 53 (3), 905-938. 
Table 1: Sample composition in 1992: Listed and non-listed firms

\begin{tabular}{lrrrrr}
\hline \hline \multirow{2}{*}{ Listing } & Legal form & All German firms & \multicolumn{3}{c}{ Sample firms } \\
\cline { 3 - 6 } & & & total & $\begin{array}{r}\text { in percent } \\
\text { of total }\end{array}$ & $\begin{array}{r}\text { in percent of } \\
\text { all German firms }\end{array}$ \\
\hline Yes & AG, KGaA & 521 & 359 & $51.0 \%$ & $68.9 \%$ \\
No & AG, KGaA & 1,643 & 233 & $33.1 \%$ & $14.2 \%$ \\
No & GmbH & 359,358 & 112 & $15.9 \%$ & $0.03 \%$ \\
\hline Total & & 361,522 & 704 & $100.0 \%$ & $0.2 \%$ \\
\hline \hline
\end{tabular}

Notes: Data on all German firms are obtained from Statistisches Bundesamt, Umsatzsteuerstatistik, Fachserie 14, Reihe 8.

Table 2: Frequency of control transfers and failure

\begin{tabular}{|c|c|c|c|c|c|c|}
\hline & & \multirow[b]{2}{*}{ Total } & \multicolumn{4}{|c|}{ Type of blockholder } \\
\hline & & & Dispersed & Private & Corporate & Government \\
\hline$(1)$ & Status in $t-1$ & 7,577 & 857 & 2,514 & 3,806 & $\overline{400}$ \\
\hline$(2)$ & No change & 6,963 & 757 & 2,336 & 3,519 & 351 \\
\hline (3) & Block sold & 576 & 96 & 159 & 275 & 46 \\
\hline (4) & Block bought & 576 & 76 & 114 & 353 & 33 \\
\hline (5) & Failure & 38 & 4 & 19 & 12 & 3 \\
\hline$(6)$ & Status in $t$ & 7,539 & 833 & 2,450 & 3,872 & 384 \\
\hline
\end{tabular}

Notes: For the definition of shareholder types see Appendix C. The rows have the following relations: $(1)=(2)+(3)+(5) ; \quad(6)=(1)-(3)+(4)-(5)=(2)+(4)$. 
Table 3: Antecedents of control transfers and failure

\begin{tabular}{|c|c|c|c|c|c|c|}
\hline & \multicolumn{3}{|c|}{ Mean } & \multicolumn{3}{|c|}{ Median } \\
\hline & $\begin{array}{c}\text { Change in } \\
\text { control }\end{array}$ & No change & Failure & $\begin{array}{l}\text { Change in } \\
\text { control }\end{array}$ & No change & Failure \\
\hline Return-on-assets & $-0.2 \% *$ & $1.0 \%$ & $-9.6 \% * *$ & $-0.3 \%^{* *}$ & $0.4 \%$ & $-5.2 \%^{* *}$ \\
\hline Debt-to-assets & $45.4 \% * *$ & $41.5 \%$ & $56.1 \%{ }^{* *}$ & $43.9 \%{ }^{* *}$ & $40.7 \%$ & $63.3 \%^{* *}$ \\
\hline Interest coverage & $56.9^{*}$ & 100.2 & $19.4^{* *}$ & $2.8^{* *}$ & 4.4 & $0.2^{* *}$ \\
\hline $\begin{array}{l}\text { Ownership } \\
\text { concentration }\end{array}$ & $56.6 \% * *$ & $68.1 \%$ & $57.1 \%+$ & $54.6 \%{ }^{* *}$ & $86.5 \%$ & $60.4 \% *$ \\
\hline Pyramid & $51.4 \%$ & $51.6 \%$ & $31.6 \% *$ & $100.0 \%$ & $100.0 \%$ & $0.0 \% *$ \\
\hline Level of pyramid & $2.0^{*}$ & 1.8 & $1.5^{*}$ & 2.0 & 2.0 & $1.0^{*}$ \\
\hline Cross-ownership & $6.4 \%$ & $8.3 \%$ & $0.0 \%+$ & $0.0 \%$ & $0.0 \%$ & $0.0 \%^{+}$ \\
\hline Total assets & $958.9^{* *}$ & 1710.0 & $662.7^{* *}$ & $192.1^{* *}$ & 231.6 & $122.1^{*}$ \\
\hline
\end{tabular}

Notes: Mean and median values calculated for firms which experience a change in ownership or failure versus mean and median values calculated for surviving firms which do not experience a change in control. The statistics are calculated for the year prior to the year in which the survival status is observed. The test statistics are heteroskedastic $t$-tests of equal means (columns 1 vs. 2 , and 2 vs. 3 ) and Wilcoxon rank-sum tests of equal medians (columns 4 vs. 5 , and 5 vs. 6 ). ${ }^{* *},{ }^{*},+$ indicates significance at the 1,5 , and 10 -percent levels, respectively. 
Table 4: Models (1) and (2), MNL model of control transfer and failure

\begin{tabular}{|c|c|c|c|c|}
\hline \multirow{2}{*}{$\begin{array}{l}\text { Model } \\
\text { Outcome (reference: No change) }\end{array}$} & \multicolumn{2}{|c|}{ (1) } & \multicolumn{2}{|c|}{ (2) } \\
\hline & Change & Fail & Change & Fail \\
\hline Industry-adjusted ROA & $\begin{array}{r}-0.858^{*} \\
(2.10)\end{array}$ & $\begin{array}{c}-5.842^{* *} \\
(4.45)\end{array}$ & $\begin{array}{r}-0.814^{*} \\
(1.99)\end{array}$ & $\begin{array}{c}-5.848^{* *} \\
(4.45)\end{array}$ \\
\hline Debt-to-assets ratio & $\begin{array}{l}0.620^{* *} \\
(3.13)\end{array}$ & $\begin{array}{l}2.332^{* *} \\
(3.12)\end{array}$ & $\begin{array}{l}0.645^{* *} \\
(3.26)\end{array}$ & $\begin{array}{l}2.325^{* *} \\
(3.11)\end{array}$ \\
\hline Herfindahl index & $\begin{array}{l}-2.107^{* *} \\
(3.65)\end{array}$ & $\begin{array}{r}0.657 \\
(0.27)\end{array}$ & $\begin{array}{c}-2.104^{* *} \\
(3.13)\end{array}$ & $\begin{array}{c}0.674 \\
(0.28)\end{array}$ \\
\hline Herfindahl index ${ }^{2}$ & $\begin{array}{l}0.929^{+} \\
(1.84)\end{array}$ & $\begin{array}{r}-1.640 \\
(0.79)\end{array}$ & $\begin{array}{r}0.883 \\
(1.59)\end{array}$ & $\begin{array}{r}-1.652 \\
(0.79)\end{array}$ \\
\hline Pyramid & $\begin{array}{r}-0.220 \\
(1.60)\end{array}$ & $\begin{array}{c}-1.047^{+} \\
(1.67)\end{array}$ & $\begin{array}{r}-0.209 \\
(1.50)\end{array}$ & $\begin{array}{c}-1.048^{+} \\
(1.67)\end{array}$ \\
\hline Level in pyramid & $\begin{array}{l}0.265^{* *} \\
(4.37)\end{array}$ & $\begin{array}{r}0.035 \\
(0.11)\end{array}$ & $\begin{array}{l}0.250^{* *} \\
(3.88)\end{array}$ & $\begin{array}{c}0.034 \\
(0.11)\end{array}$ \\
\hline Cross-ownership & $\begin{array}{c}-0.299^{+} \\
(1.67)\end{array}$ & & $\begin{array}{r}-0.420^{*} \\
(2.25)\end{array}$ & \\
\hline $\log$ (Assets) & $\begin{array}{c}-0.100^{* *} \\
(4.39)\end{array}$ & $\begin{array}{c}-0.183^{*} \\
(2.13)\end{array}$ & $\begin{array}{c}-0.105^{* *} \\
(4.61)\end{array}$ & $\begin{array}{r}-0.183^{*} \\
(2.13)\end{array}$ \\
\hline Listed & $\begin{array}{r}-0.047 \\
(0.41)\end{array}$ & $\begin{array}{c}-4.335^{* *} \\
(4.23)\end{array}$ & $\begin{array}{r}-0.004 \\
(0.03)\end{array}$ & $\begin{array}{c}-4.332^{\text {** }} \\
(4.23)\end{array}$ \\
\hline $\mathrm{GmbH}$ & $\begin{array}{r}-0.142 \\
(1.06)\end{array}$ & $\begin{array}{l}-2.404^{* *} \\
(4.74)\end{array}$ & $\begin{array}{r}-0.165 \\
(1.23)\end{array}$ & $\begin{array}{c}-2.400 \text { ** } \\
(4.73)\end{array}$ \\
\hline Time trend & $\begin{array}{c}0.002 \\
(0.11)\end{array}$ & $\begin{array}{l}0.421^{* *} \\
(4.34)\end{array}$ & $\begin{array}{r}0.000 \\
(0.03)\end{array}$ & $\begin{array}{l}0.4211^{\text {** }} \\
(4.34)\end{array}$ \\
\hline
\end{tabular}

Ownership type (reference: Corporate)

Dispersed

Private

$-0.353^{* *}$

$(3.20)$

Government

0.164

$(0.87)$

\begin{tabular}{lrr}
\hline Number of observations: & 7,577 & 7,577 \\
Log Likelihood: & $-2,142.9$ & $-2,136.1$ \\
LR test against constants only: & $261.9^{* *}$ (21 d.f.) & $275.5^{* *}(24$ d.f. $)$ \\
LR test model (2) against (1): & & $13.6^{* *}$ (3 d.f.) \\
\hline \hline
\end{tabular}

Asymptotic $t$-statistics in parentheses. Constants are included but not reported.

${ }^{* *}, *,+$ : significantly different from zero at the $1,5,10$-percent level, respectively. 
Table 5: Model (3), Interactions with type of seller

\begin{tabular}{|c|c|c|c|c|c|}
\hline \multirow{2}{*}{$\begin{array}{l}\text { Outcome } \\
\text { Type }\end{array}$} & \multirow{2}{*}{$\begin{array}{c}\text { Change } \\
\text { Corporate }\end{array}$} & \multicolumn{3}{|c|}{ Change (difference to corporate) } & \multirow[t]{2}{*}{ Fail } \\
\hline & & Dispersed & Private & Government & \\
\hline Industry-adjusted ROA & $\begin{array}{c}-0.937 \\
(1.69)\end{array}$ & $\begin{array}{r}-0.079 \\
(0.05)\end{array}$ & $\begin{array}{c}0.714 \\
(0.79)\end{array}$ & $\begin{array}{c}0.182 \\
(0.10)\end{array}$ & $\begin{array}{c}-5.849^{* *} \\
(4.46)\end{array}$ \\
\hline Debt-to-assets ratio & $\begin{array}{c}0.279 \\
(1.01)\end{array}$ & $\begin{array}{r}0.511 \\
(0.83)\end{array}$ & $\begin{array}{c}1.111 \\
(2.22)\end{array}$ & $\begin{array}{r}0.470 \\
(0.59)\end{array}$ & $\begin{array}{l}2.344^{* *} \\
(3.14)\end{array}$ \\
\hline Herfindahl index & $\begin{array}{c}-3.863^{\text {** }} \\
(3.53)\end{array}$ & $\begin{array}{l}8.722^{* *} \\
(3.35)\end{array}$ & $\begin{array}{r}-0.418 \\
(0.22)\end{array}$ & $\begin{array}{l}1.764 \\
(0.53)\end{array}$ & $\begin{array}{c}0.680 \\
(0.28)\end{array}$ \\
\hline Herfindahl index ${ }^{2}$ & $\begin{array}{l}2.118 \text { * } \\
(2.34)\end{array}$ & $\begin{array}{r}-11.031 \\
(2.09)\end{array}$ & $\begin{array}{c}0.573 \\
(0.36)\end{array}$ & $\begin{array}{r}-0.970 \\
(0.36)\end{array}$ & $\begin{array}{r}-1.662 \\
(0.80)\end{array}$ \\
\hline Pyramid & $\begin{array}{r}-0.239 \\
(1.13)\end{array}$ & $\begin{array}{r}0.762 \\
(1.47)\end{array}$ & $\begin{array}{c}-0.657^{+} \\
(1.89)\end{array}$ & $\begin{array}{l}2.033^{* *} \\
(3.17)\end{array}$ & $\begin{array}{c}-1.043^{+} \\
(1.67)\end{array}$ \\
\hline Level in pyramid & $\begin{array}{r}0.170 \\
(1.55)\end{array}$ & $\begin{array}{r}-0.444 \\
(1.34)\end{array}$ & $\begin{array}{l}0.552^{* *} \\
(3.49)\end{array}$ & $\begin{array}{r}-0.428^{*} \\
(2.25)\end{array}$ & $\begin{array}{r}0.026 \\
(0.08)\end{array}$ \\
\hline Cross-ownership & $\begin{array}{c}-0.407^{*} \\
(2.12)\end{array}$ & & & & \\
\hline $\log$ (Assets) & $\begin{array}{c}-0.096^{\text {** }} \\
(2.91)\end{array}$ & $\begin{array}{r}-0.034 \\
(0.53)\end{array}$ & $\begin{array}{r}-0.041 \\
(0.68)\end{array}$ & $\begin{array}{c}0.073 \\
(0.72)\end{array}$ & $\begin{array}{c}-0.186{ }^{*} \\
(2.16)\end{array}$ \\
\hline Listed & $\begin{array}{r}0.078 \\
(0.47)\end{array}$ & $\begin{array}{r}-0.352 \\
(1.04)\end{array}$ & $\begin{array}{c}0.075 \\
(0.27)\end{array}$ & $\begin{array}{r}-0.010 \\
(0.02)\end{array}$ & $\begin{array}{c}-4.332^{* *} \\
(4.23)\end{array}$ \\
\hline $\mathrm{GmbH}$ & $\begin{array}{r}-0.216 \\
(1.20)\end{array}$ & $\begin{array}{r}-0.550 \\
(1.05)\end{array}$ & $\begin{array}{c}0.208 \\
(0.61)\end{array}$ & $\begin{array}{r}0.551 \\
(1.10)\end{array}$ & $\begin{array}{c}-2.408^{* *} \\
(4.75)\end{array}$ \\
\hline Time trend & $\begin{array}{c}0.024 \\
(0.92)\end{array}$ & $\begin{array}{r}-0.044 \\
(0.93)\end{array}$ & $\begin{array}{r}0.026 \\
(0.61)\end{array}$ & $\begin{array}{c}-0.273^{* *} \\
(3.85)\end{array}$ & $\begin{array}{l}0.421 \\
(4.35)\end{array}$ \\
\hline \multicolumn{2}{|l|}{ Number of observations: } & 7,577 & & & \\
\hline \multicolumn{2}{|l|}{ Log Likelihood: } & $-2,081.3$ & & & \\
\hline \multicolumn{2}{|c|}{ LR test against constants only: } & $385.0^{* *}$ & 54 d.f.) & & \\
\hline \multicolumn{2}{|c|}{ LR test against Model (2): } & $109.6^{* *}$ & 30 d.f.) & & \\
\hline
\end{tabular}

Asymptotic $t$-statistics in parentheses. Constants are included but not reported. $* *, *,+$ : significantly different from zero at the $1,5,10$-percent level, respectively. 
Table 6: Model (4), Splitting the types of buyers

\begin{tabular}{|c|c|c|c|c|c|}
\hline \multirow[t]{2}{*}{ Outcome } & \multicolumn{4}{|c|}{ Change to... } & \multirow[t]{2}{*}{ Fail } \\
\hline & Dispersed & Private & Corporate & Government & \\
\hline Industry-adjusted ROA & $\begin{array}{r}-1.683 \\
(1.35)\end{array}$ & $\begin{array}{r}-0.656 \\
(0.75)\end{array}$ & $\begin{array}{r}-0.638 \\
(1.28)\end{array}$ & $\begin{array}{c}-2.981 \\
(1.92)\end{array}$ & $\begin{array}{c}-5.844^{* *} \\
(4.45)\end{array}$ \\
\hline Debt-to-assets ratio & $\begin{array}{c}0.603 \\
(1.05)\end{array}$ & $\begin{array}{r}0.601 \\
(1.40)\end{array}$ & $\begin{array}{l}0.617^{*} \\
(2.51)\end{array}$ & $\begin{array}{c}0.698 \\
(0.85)\end{array}$ & $\begin{array}{l}2.332^{* *} \\
(3.12)\end{array}$ \\
\hline Herfindahl index & $\begin{array}{r}-1.076 \\
(0.76)\end{array}$ & $\begin{array}{l}0.052 \\
(0.04)\end{array}$ & $\begin{array}{c}-2.219^{* *} \\
(2.86)\end{array}$ & $\begin{array}{c}-4.739+ \\
(1.81)\end{array}$ & $\begin{array}{c}0.688 \\
(0.28)\end{array}$ \\
\hline Herfindahl index ${ }^{2}$ & $\begin{array}{r}-3.016 \text { * } \\
(2.00)\end{array}$ & $\begin{array}{r}-0.929 \\
(0.87)\end{array}$ & $\begin{array}{l}1.398 \text { * } \\
(2.09)\end{array}$ & $\begin{array}{r}3.422 \\
(1.48)\end{array}$ & $\begin{array}{r}-1.660 \\
(0.80)\end{array}$ \\
\hline Pyramid & $\begin{array}{c}0.009 \\
(0.02)\end{array}$ & $\begin{array}{c}-1.111^{* *} \\
(2.84)\end{array}$ & $\begin{array}{r}-0.014 \\
(0.08)\end{array}$ & $\begin{array}{r}0.441 \\
(0.79)\end{array}$ & $\begin{array}{c}-1.041 \\
(1.66)\end{array}$ \\
\hline Level in pyramid & $\begin{array}{c}0.174 \\
(0.82)\end{array}$ & $\begin{array}{c}0.090 \\
(0.45)\end{array}$ & $\begin{array}{l}0.337^{* *} \\
(5.02)\end{array}$ & $\begin{array}{r}-0.204 \\
(0.75)\end{array}$ & $\begin{array}{c}0.031 \\
(0.10)\end{array}$ \\
\hline Cross-ownership & $\begin{array}{l}0.710^{+} \\
(1.91)\end{array}$ & $\begin{array}{r}-0.381 \\
(0.82)\end{array}$ & $\begin{array}{c}-1.577^{* *} \\
(4.34)\end{array}$ & $\begin{array}{l}2.280 \text { ** } \\
(6.11)\end{array}$ & \\
\hline $\log ($ Assets $)$ & $\begin{array}{r}-0.042 \\
(0.69)\end{array}$ & $\begin{array}{c}-0.204^{* *} \\
(4.10)\end{array}$ & $\begin{array}{c}-0.107^{* *} \\
(3.69)\end{array}$ & $\begin{array}{c}0.110 \\
(1.16)\end{array}$ & $\begin{array}{r}-0.184 \\
(2.14)\end{array}$ \\
\hline Listed & $\begin{array}{r}0.371 \\
(1.08)\end{array}$ & $\begin{array}{c}0.224 \\
(0.89)\end{array}$ & $\begin{array}{c}-0.249^{+} \\
(1.72)\end{array}$ & $\begin{array}{r}0.230 \\
(0.43)\end{array}$ & $\begin{array}{c}-4.327^{* *} \\
(4.22)\end{array}$ \\
\hline $\mathrm{GmbH}$ & $\begin{array}{r}0.400 \\
(0.89)\end{array}$ & $\begin{array}{r}0.233 \\
(0.72)\end{array}$ & $\begin{array}{c}-0.348^{*} \\
(2.20)\end{array}$ & $\begin{array}{r}0.368 \\
(0.70)\end{array}$ & $\begin{array}{c}-2.398^{* *} \\
(4.73)\end{array}$ \\
\hline Time trend & $\begin{array}{c}0.026 \\
(0.59)\end{array}$ & $\begin{array}{r}-0.007 \\
(0.20)\end{array}$ & $\begin{array}{r}-0.010 \\
(0.47)\end{array}$ & $\begin{array}{c}0.082 \\
(1.11)\end{array}$ & $\begin{array}{l}0.420^{\text {** }} \\
(4.34)\end{array}$ \\
\hline \multicolumn{2}{|l|}{ Number of observations: } & 7,577 & & & \\
\hline \multicolumn{2}{|l|}{ Log Likelihood: } & $-2,644.3$ & & & \\
\hline \multicolumn{2}{|c|}{ LR test against constants only: } & $470.7^{*}$ & 54 d.f.) & & \\
\hline
\end{tabular}

Asymptotic $t$-statistics in parentheses. Constants are included but not reported.

$* *, *,+$ : significantly different from zero at the $1,5,10$-percent level, respectively. 
Table 7: Model (5), Full model: interactions with type of seller

\begin{tabular}{|c|c|c|c|c|c|}
\hline \multirow{3}{*}{$\begin{array}{l}\text { Outcome } \\
\text { Effect } \\
\text { Seller Type }\end{array}$} & \multicolumn{4}{|c|}{ Change to corporate } & \multirow[t]{3}{*}{ Fail } \\
\hline & \multirow{2}{*}{$\begin{array}{c}\text { absolute } \\
\text { Corporate }\end{array}$} & \multicolumn{3}{|c|}{ relative to corporate seller } & \\
\hline & & Dispersed & Private & Government & \\
\hline Industry-adjusted ROA & $\begin{array}{r}-0.685 \\
(1.09)\end{array}$ & $\begin{array}{r}-0.011 \\
(0.01)\end{array}$ & $\begin{array}{r}0.591 \\
(0.65)\end{array}$ & $\begin{array}{l}0.051 \\
(0.03)\end{array}$ & $\begin{array}{c}-5.851 \\
(4.46)\end{array}$ \\
\hline Debt-to-assets ratio & $\begin{array}{c}0.271 \\
(0.86)\end{array}$ & $\begin{array}{c}0.503 \\
(0.81)\end{array}$ & $\begin{array}{l}1.077^{*} \\
(2.14)\end{array}$ & $\begin{array}{c}0.504 \\
(0.63)\end{array}$ & $\begin{array}{l}2.345^{\text {** }} \\
(3.14)\end{array}$ \\
\hline Herfindahl index & $\begin{array}{c}-3.224^{*} \\
(2.56)\end{array}$ & $\begin{array}{l}7.637^{* *} \\
(2.92)\end{array}$ & $\begin{array}{r}-1.030 \\
(0.54)\end{array}$ & $\begin{array}{l}1.393 \\
(0.42)\end{array}$ & $\begin{array}{c}0.693 \\
(0.28)\end{array}$ \\
\hline Herfindahl index ${ }^{2}$ & $\begin{array}{l}2.001 \\
(1.92)\end{array}$ & $\begin{array}{c}-9.883^{+} \\
(1.87)\end{array}$ & $\begin{array}{l}1.004 \\
(0.63)\end{array}$ & $\begin{array}{r}-0.765 \\
(0.28)\end{array}$ & $\begin{array}{r}-1.669 \\
(0.81)\end{array}$ \\
\hline Pyramid & $\begin{array}{r}-0.108 \\
(0.46)\end{array}$ & $\begin{array}{c}0.834 \\
(1.59)\end{array}$ & $\begin{array}{r}-0.533 \\
(1.52)\end{array}$ & $\begin{array}{l}2.114^{* *} \\
(3.28)\end{array}$ & $\begin{array}{c}-1.039+ \\
(1.66)\end{array}$ \\
\hline Level in pyramid & $\begin{array}{c}0.289 \text { * } \\
(2.42)\end{array}$ & $\begin{array}{r}-0.489 \\
(1.47)\end{array}$ & $\begin{array}{l}0.471^{* *} \\
(2.93)\end{array}$ & $\begin{array}{c}-0.506^{* *} \\
(2.63)\end{array}$ & $\begin{array}{c}0.025 \\
(0.08)\end{array}$ \\
\hline Cross-ownership & $\begin{array}{c}-1.623^{* *} \\
(4.38)\end{array}$ & & & & \\
\hline $\log$ (Assets) & $\begin{array}{c}-0.113^{* *} \\
(3.01)\end{array}$ & $\begin{array}{r}-0.025 \\
(0.38)\end{array}$ & $\begin{array}{r}-0.023 \\
(0.37)\end{array}$ & $\begin{array}{c}0.088 \\
(0.87)\end{array}$ & $\begin{array}{c}-0.186 \text { * } \\
(2.17)\end{array}$ \\
\hline Listed & $\begin{array}{r}-0.150 \\
(0.78)\end{array}$ & $\begin{array}{r}-0.360 \\
(1.05)\end{array}$ & $\begin{array}{r}0.137 \\
(0.48)\end{array}$ & $\begin{array}{r}0.087 \\
(0.14)\end{array}$ & $\begin{array}{c}-4.327^{\text {** }} \\
(4.22)\end{array}$ \\
\hline $\mathrm{GmbH}$ & $\begin{array}{r}-0.456 \text { * } \\
(2.21)\end{array}$ & $\begin{array}{r}-0.600 \\
(1.14)\end{array}$ & $\begin{array}{c}0.284 \\
(0.83)\end{array}$ & $\begin{array}{r}0.682 \\
(1.35)\end{array}$ & $\begin{array}{c}-2.404^{* *} \\
(4.74)\end{array}$ \\
\hline Time trend & $\begin{array}{l}0.010 \\
(0.33)\end{array}$ & $\begin{array}{r}-0.042 \\
(0.88)\end{array}$ & $\begin{array}{c}0.034 \\
(0.80)\end{array}$ & $\begin{array}{c}-0.266^{* *} \\
(3.74)\end{array}$ & $\begin{array}{l}0.421^{* *} \\
(4.35)\end{array}$ \\
\hline Number of observations: & & 7,577 & & & \\
\hline Log Likelihood: & & $-2,586.2$ & & & \\
\hline LR test against constant & only: & $586.8^{* *}$ & 7 d.f.) & & \\
\hline
\end{tabular}

Asymptotic $t$-statistics in parentheses. Constants are included but not reported.

$* *, *,+$ : significantly different from zero at the $1,5,10$-percent level, respectively.

The interactions with the type of buyer that are also included in this model are shown in Table 8. 
Table 8: Model (5) continued, Full model: interactions with type of buyer

\begin{tabular}{|c|c|c|c|c|}
\hline \multirow{2}{*}{$\begin{array}{l}\text { Outcome } \\
\text { Shareholder Type }\end{array}$} & \multirow{2}{*}{$\begin{array}{l}\text { Change } \\
\text { Corporate }\end{array}$} & \multicolumn{3}{|c|}{ Change to ...(difference to corporate) } \\
\hline & & Dispersed & Private & Government \\
\hline Industry-adjusted ROA & $\begin{array}{r}-0.685 \\
(1.09)\end{array}$ & $\begin{array}{r}-0.927 \\
(0.69)\end{array}$ & $\begin{array}{r}0.019 \\
(0.02)\end{array}$ & $\begin{array}{r}-2.318 \\
(1.42)\end{array}$ \\
\hline Debt-to-assets ratio & $\begin{array}{r}0.271 \\
(0.86)\end{array}$ & $\begin{array}{r}-0.004 \\
(0.01)\end{array}$ & $\begin{array}{r}0.057 \\
(0.12)\end{array}$ & $\begin{array}{r}0.207 \\
(0.24)\end{array}$ \\
\hline Herfindahl index & $\begin{array}{c}-3.224 \\
(2.56)\end{array}$ & $\begin{array}{r}0.555 \\
(0.33)\end{array}$ & $\begin{array}{c}2.239 \\
(1.49)\end{array}$ & $\begin{array}{r}-2.880 \\
(0.99)\end{array}$ \\
\hline Herfindahl index ${ }^{2}$ & $\begin{array}{l}2.001 \\
(1.92)\end{array}$ & $\begin{array}{r}-3.781 \\
(2.26)\end{array}$ & $\begin{array}{c}-2.232^{+} \\
(1.71)\end{array}$ & $\begin{array}{r}2.441 \\
(0.96)\end{array}$ \\
\hline Pyramid & $\begin{array}{r}-0.108 \\
(0.46)\end{array}$ & $\begin{array}{r}-0.066 \\
(0.15)\end{array}$ & $\begin{array}{r}-1.065^{*} \\
(2.49)\end{array}$ & $\begin{array}{c}0.413 \\
(0.71)\end{array}$ \\
\hline Level in pyramid & $\begin{array}{c}0.289^{*} \\
(2.42)\end{array}$ & $\begin{array}{r}-0.099 \\
(0.42)\end{array}$ & $\begin{array}{r}-0.249 \\
(1.17)\end{array}$ & $\begin{array}{c}-0.485^{+} \\
(1.71)\end{array}$ \\
\hline Cross-ownership & $\begin{array}{c}-1.623^{* *} \\
(4.38)\end{array}$ & $\begin{array}{l}2.052^{* *} \\
(3.91)\end{array}$ & $\begin{array}{c}1.049 \\
(1.78)\end{array}$ & $\begin{array}{l}3.732^{* *} \\
(7.22)\end{array}$ \\
\hline $\log$ (Assets) & $\begin{array}{c}-0.113^{* *} \\
(3.01)\end{array}$ & $\begin{array}{c}0.072 \\
(1.05)\end{array}$ & $\begin{array}{r}-0.090 \\
(1.59)\end{array}$ & $\begin{array}{c}0.218 \text { * } \\
(2.18)\end{array}$ \\
\hline Listed & $\begin{array}{r}-0.150 \\
(0.78)\end{array}$ & $\begin{array}{l}0.610^{+} \\
(1.65)\end{array}$ & $\begin{array}{r}0.470 \\
(1.64)\end{array}$ & $\begin{array}{c}0.420 \\
(0.75)\end{array}$ \\
\hline $\mathrm{GmbH}$ & $\begin{array}{c}-0.456^{*} \\
(2.21)\end{array}$ & $\begin{array}{l}0.812^{+} \\
(1.69)\end{array}$ & $\begin{array}{c}0.584 \\
(1.62)\end{array}$ & $\begin{array}{r}0.711 \\
(1.29)\end{array}$ \\
\hline Time trend & $\begin{array}{r}0.010 \\
(0.33)\end{array}$ & $\begin{array}{c}0.039 \\
(0.80)\end{array}$ & $\begin{array}{r}-0.009 \\
(0.21)\end{array}$ & $\begin{array}{c}0.087 \\
(1.13)\end{array}$ \\
\hline
\end{tabular}

Asymptotic $t$-statistics in parentheses. Constants are included but not reported.

$* *, *,+$ : significantly different from zero at the $1,5,10$-percent level, respectively. 
Table 9: MNL and MMNL model of control transfer and failure

\begin{tabular}{|c|c|c|c|c|}
\hline \multirow{2}{*}{$\begin{array}{l}\text { Model } \\
\text { Outcome (reference: No change) }\end{array}$} & \multicolumn{2}{|c|}{$\mathrm{MNL}=$ Model $(1)$} & \multicolumn{2}{|c|}{ Mixed Logit (MMNL) } \\
\hline & Change & Fail & Change & Fail \\
\hline Industry-adjusted ROA & $\begin{array}{c}-0.8588^{*} \\
(2.10)\end{array}$ & $\begin{array}{c}-5.842^{* *} \\
(4.45)\end{array}$ & $\begin{array}{c}-0.866^{*} \\
(2.01)\end{array}$ & $\begin{array}{c}-6.031 \\
(4.25)\end{array}$ \\
\hline Debt-to-assets ratio & $\begin{array}{l}0.620^{* *} \\
(3.13)\end{array}$ & $\begin{array}{l}2.332^{* *} \\
(3.12)\end{array}$ & $\begin{array}{l}0.659^{* *} \\
(3.10)\end{array}$ & $\begin{array}{l}2.355^{* *} \\
(2.82)\end{array}$ \\
\hline Herfindahl index & $\begin{array}{c}-2.107^{* *} \\
(3.65)\end{array}$ & $\begin{array}{c}0.657 \\
(0.27)\end{array}$ & $\begin{array}{c}-2.430 \\
(3.70)\end{array}$ & $\begin{array}{c}0.460 \\
(0.17)\end{array}$ \\
\hline Herfindahl index ${ }^{2}$ & $\begin{array}{l}0.929^{+} \\
(1.84)\end{array}$ & $\begin{array}{r}-1.640 \\
(0.79)\end{array}$ & $\begin{array}{c}1.122^{*} \\
(1.97)\end{array}$ & $\begin{array}{r}-1.538 \\
(0.72)\end{array}$ \\
\hline Pyramid & $\begin{array}{r}-0.220 \\
(1.60)\end{array}$ & $\begin{array}{l}-1.047^{+} \\
(1.67)\end{array}$ & $\begin{array}{c}-0.263^{+} \\
(1.70)\end{array}$ & $\begin{array}{c}-1.064 \\
(1.74)\end{array}$ \\
\hline Level in pyramid & $\begin{array}{l}0.265^{* *} \\
(4.37)\end{array}$ & $\begin{array}{c}0.035 \\
(0.11)\end{array}$ & $\begin{array}{l}0.284^{* *} \\
(4.27)\end{array}$ & $\begin{array}{c}0.048 \\
(0.16)\end{array}$ \\
\hline Cross-ownership & $\begin{array}{c}-0.299+ \\
(1.67)\end{array}$ & & $\begin{array}{r}-0.333 \\
(1.60)\end{array}$ & \\
\hline $\log$ (Assets) & $\begin{array}{c}-0.100^{* *} \\
(4.39)\end{array}$ & $\begin{array}{c}-0.183^{*} \\
(2.13)\end{array}$ & $\begin{array}{c}-0.108^{* *} \\
(4.07)\end{array}$ & $\begin{array}{c}-0.190 \text { ** } \\
(2.62)\end{array}$ \\
\hline Listed & $\begin{array}{r}-0.047 \\
(0.41)\end{array}$ & $\begin{array}{c}-4.335^{* *} \\
(4.23)\end{array}$ & $\begin{array}{r}-0.072 \\
(0.53)\end{array}$ & $\begin{array}{c}-4.388^{* *} \\
(4.14)\end{array}$ \\
\hline $\mathrm{GmbH}$ & $\begin{array}{r}-0.142 \\
(1.06)\end{array}$ & $\begin{array}{c}-2.404^{* *} \\
(4.74)\end{array}$ & $\begin{array}{r}-0.155 \\
(1.05)\end{array}$ & $\begin{array}{c}-2.440 \text { ** } \\
(4.68)\end{array}$ \\
\hline Time trend & $\begin{array}{r}0.002 \\
(0.11)\end{array}$ & $\begin{array}{l}0.421^{* *} \\
(4.34)\end{array}$ & $\begin{array}{c}0.004 \\
(0.22)\end{array}$ & $\begin{array}{l}0.428^{* *} \\
(5.64)\end{array}$ \\
\hline \multicolumn{5}{|c|}{ Std. dev. of firm-specific random effects (unobs. heterogeneity): } \\
\hline Change & $\begin{array}{r}0 \\
(\text { constr. })\end{array}$ & & $\begin{array}{l}0.561^{* *} \\
(4.68)\end{array}$ & \\
\hline \multicolumn{5}{|c|}{ Std. dev. of contemporaneous shocks (correlations): } \\
\hline Change \& Fail & $\begin{array}{r}0 \\
(\text { constr. })\end{array}$ & & $\begin{array}{l}0.674^{*} \\
(2.42)\end{array}$ & \\
\hline $\begin{array}{l}\text { Number of observations: } \\
\text { Log Likelihood: } \\
\text { LR test MNL against MMNL: }\end{array}$ & $\begin{array}{r}7,577 \\
-2,142.9\end{array}$ & & $\begin{array}{r}7,577 \\
-2,135.8 \\
14.2\end{array}$ & 2 d.f.) \\
\hline
\end{tabular}

Asymptotic $t$-statistics in parentheses. Constants are included but not reported.

$* *, *,+$ : significantly different from zero at the $1,5,10$-percent level, respectively. 
Table 10: MMNL model for buyers, corresponds to Model (4)

\begin{tabular}{|c|c|c|c|c|c|}
\hline \multirow[t]{2}{*}{ Outcome } & \multicolumn{4}{|c|}{ Change to... } & \multirow{2}{*}{ Fail } \\
\hline & Dispersed & Private & Corporate & Government & \\
\hline Industry-adjusted ROA & $\begin{array}{r}-1.636 \\
(0.97)\end{array}$ & $\begin{array}{r}-0.709 \\
(0.67)\end{array}$ & $\begin{array}{r}-0.781 \\
(1.50)\end{array}$ & $\begin{array}{c}-3.292 \\
(1.69)\end{array}$ & $\begin{array}{c}-6.332^{* *} \\
(4.03)\end{array}$ \\
\hline Debt-to-assets ratio & $\begin{array}{c}0.390 \\
(0.57)\end{array}$ & $\begin{array}{c}0.690 \\
(1.25)\end{array}$ & $\begin{array}{c}0.750 \text { * } \\
(2.41)\end{array}$ & $\begin{array}{c}0.867 \\
(0.83)\end{array}$ & $\begin{array}{c}2.352 \\
(2.19)\end{array}$ \\
\hline Herfindahl index & $\begin{array}{c}-8.741^{* *} \\
(4.02)\end{array}$ & $\begin{array}{r}-0.364 \\
(0.26)\end{array}$ & $\begin{array}{c}-2.670 \\
(2.61)\end{array}$ & $\begin{array}{c}-5.410^{+} \\
(1.80)\end{array}$ & $\begin{array}{r}0.262 \\
(0.09)\end{array}$ \\
\hline Herfindahl index ${ }^{2}$ & $\begin{array}{r}3.046 \\
(1.55)\end{array}$ & $\begin{array}{r}-0.766 \\
(0.61)\end{array}$ & $\begin{array}{l}1.603^{+} \\
(1.89)\end{array}$ & $\begin{array}{r}3.746 \\
(1.39)\end{array}$ & $\begin{array}{r}-1.381 \\
(0.49)\end{array}$ \\
\hline Pyramid & $\begin{array}{r}-0.205 \\
(0.40)\end{array}$ & $\begin{array}{c}-1.182^{* *} \\
(2.87)\end{array}$ & $\begin{array}{r}-0.117 \\
(0.57)\end{array}$ & $\begin{array}{c}0.503 \\
(0.58)\end{array}$ & $\begin{array}{r}-1.223 \\
(1.48)\end{array}$ \\
\hline Level in pyramid & $\begin{array}{l}0.239 \\
(0.82)\end{array}$ & $\begin{array}{c}0.137 \\
(0.68)\end{array}$ & $\begin{array}{l}0.405^{* *} \\
(4.44)\end{array}$ & $\begin{array}{r}-0.221 \\
(0.44)\end{array}$ & $\begin{array}{c}0.229 \\
(0.61)\end{array}$ \\
\hline Cross-ownership & $\begin{array}{c}0.000 \\
(0.00)\end{array}$ & $\begin{array}{r}-0.444 \\
(0.82)\end{array}$ & $\begin{array}{c}-1.709^{* *} \\
(4.27)\end{array}$ & $\begin{array}{l}2.304^{* *} \\
(4.47)\end{array}$ & \\
\hline $\log$ (Assets) & $\begin{array}{r}-0.019 \\
(0.21)\end{array}$ & $\begin{array}{c}-0.224^{* *} \\
(3.63)\end{array}$ & $\begin{array}{c}-0.130 \\
(3.49)\end{array}$ & $\begin{array}{l}0.125 \\
(0.86)\end{array}$ & $\begin{array}{r}-0.217 \\
(1.64)\end{array}$ \\
\hline Listed & $\begin{array}{c}0.380 \\
(0.89)\end{array}$ & $\begin{array}{c}0.145 \\
(0.48)\end{array}$ & $\begin{array}{c}-0.334^{+} \\
(1.95)\end{array}$ & $\begin{array}{c}0.231 \\
(0.33)\end{array}$ & $\begin{array}{c}-4.479^{* *} \\
(3.87)\end{array}$ \\
\hline $\mathrm{GmbH}$ & $\begin{array}{r}0.371 \\
(0.66)\end{array}$ & $\begin{array}{l}0.167 \\
(0.47)\end{array}$ & $\begin{array}{c}-0.417^{*} \\
(2.17)\end{array}$ & $\begin{array}{r}0.401 \\
(0.58)\end{array}$ & $\begin{array}{c}-2.593^{* *} \\
(3.08)\end{array}$ \\
\hline Time trend & $\begin{array}{c}0.460 \\
(0.93)\end{array}$ & $\begin{array}{r}-0.031 \\
(0.08)\end{array}$ & $\begin{array}{r}-0.064 \\
(0.27)\end{array}$ & $\begin{array}{r}0.885 \\
(0.76)\end{array}$ & $\begin{array}{l}4.364^{* *} \\
(2.83)\end{array}$ \\
\hline
\end{tabular}

Std. dev. of firm-specific random effects (unobs. heterogeneity):

Change

$0.698^{* *}$

Std. dev. of contemporaneous shocks (correlations):

All Change Outcomes

$$
\begin{gathered}
-0.164^{*} \\
(0.40)
\end{gathered}
$$

All Change Outcomes \& Fail

Number of observations:

Log Likelihood:

LR test against Model (4):

\section{7,577}

$-2,595.1$

$98.5^{* *}(3$ d.f. $)$

Asymptotic $t$-statistics in parentheses. Constants are included but not reported. $* *, *,+$ : significantly different from zero at the 1, 5, 10-percent level, respectively. 
Table 11: Robustness tests: Performance variables

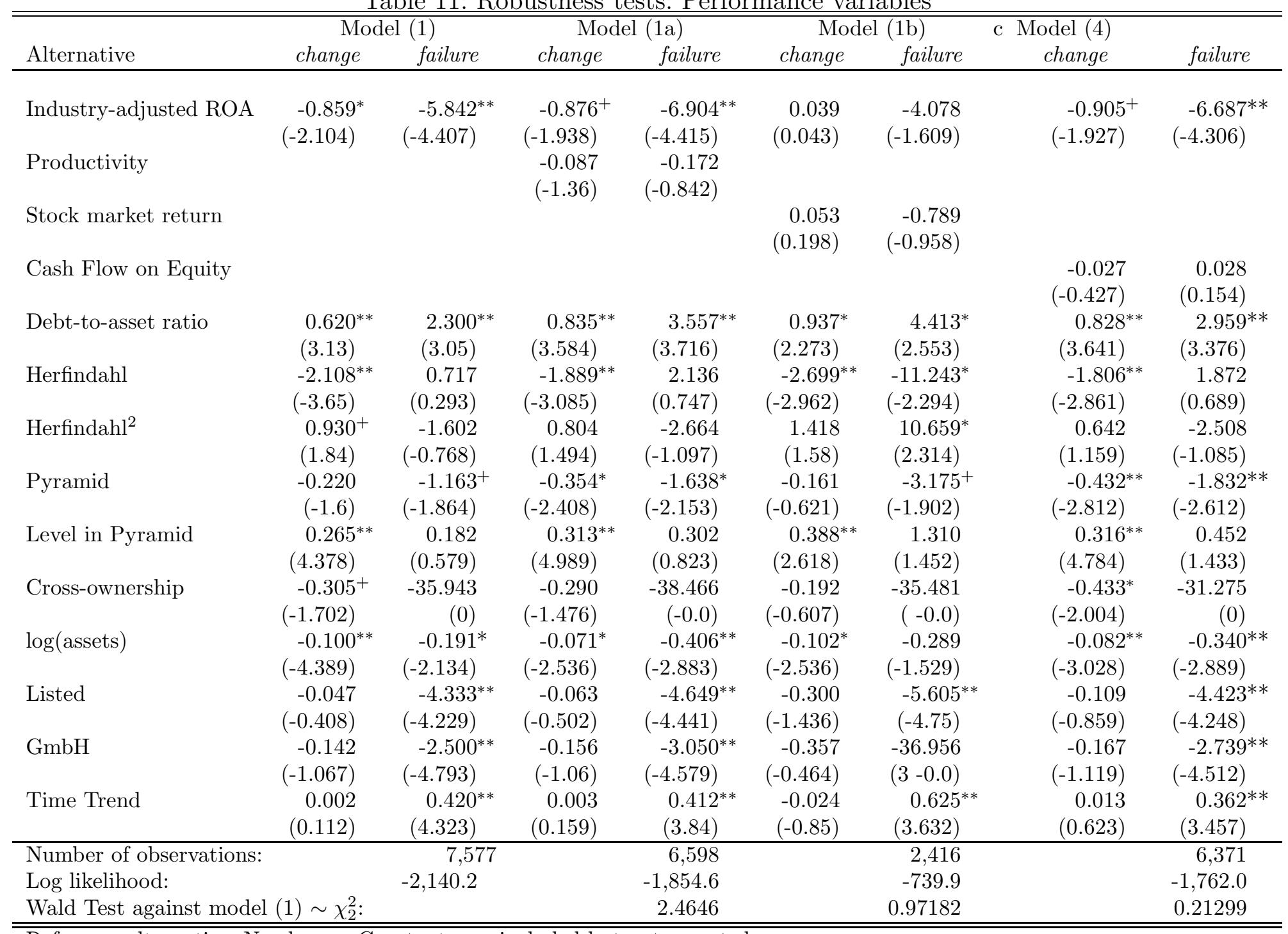

Reference alternative: No change. Constants are included but not reported.

$* *, *,+$ : significantly different from zero at the $1,5,10$-percent level, respectively. 
Table 12: Robustness tests: Financial pressure variables

\begin{tabular}{|c|c|c|c|c|c|c|c|c|}
\hline \multirow[b]{2}{*}{ Alternative } & \multicolumn{2}{|c|}{ Model (1) } & \multicolumn{2}{|c|}{ Model (1d) } & \multicolumn{2}{|c|}{ Model (1e) } & \multicolumn{2}{|c|}{ Model (1f) } \\
\hline & change & failure & change & failure & change & failure & change & failure \\
\hline \multirow[t]{2}{*}{ Industry-adjusted ROA } & $-0.859^{*}$ & $-5.842^{* *}$ & $-1.146^{* *}$ & $-6.028^{* *}$ & $-0.869^{*}$ & $-6.051^{* *}$ & $-0.850^{*}$ & $-5.807^{* *}$ \\
\hline & $(-2.104)$ & $(-4.407)$ & $(-2.689)$ & $(-4.426)$ & $(-2.03)$ & $(-4.502)$ & $(-1.984)$ & $(-4.347)$ \\
\hline \multirow[t]{2}{*}{ Debt-to-assets ratio } & $0.620^{* *}$ & $2.300^{* *}$ & $0.598^{* *}$ & $2.378^{* *}$ & $0.733^{* *}$ & $2.552^{* *}$ & $0.904^{* *}$ & $2.385^{* *}$ \\
\hline & $(3.13)$ & $(3.05)$ & $(2.844)$ & $(2.978)$ & $(3.277)$ & $(3.209)$ & $(4.109)$ & $(3.093)$ \\
\hline \multirow[t]{2}{*}{ Interest coverage } & & & 0.000 & 0.000 & & & & \\
\hline & & & $(-0.792)$ & $(-0.165)$ & & & & \\
\hline \multirow[t]{2}{*}{ No working capital } & & & & & 0.090 & $-0.974^{+}$ & & \\
\hline & & & & & $(0.627)$ & $(-1.686)$ & & \\
\hline Current ratio & & & & & & & $\begin{array}{c}0.002^{+} \\
(1.958)\end{array}$ & $\begin{array}{c}0.005+ \\
(1.839)\end{array}$ \\
\hline \multirow[t]{2}{*}{ Herfindahl } & $-2.108^{* *}$ & 0.717 & $-1.984^{* *}$ & 0.875 & $-2.306^{* *}$ & 0.585 & $-2.272^{* *}$ & 0.805 \\
\hline & $(-3.65)$ & $(0.293)$ & $(-3.404)$ & $(0.352)$ & $(-3.798)$ & $(0.237)$ & $(-3.732)$ & $(0.328)$ \\
\hline \multirow[t]{2}{*}{ Herfindahl $^{2}$} & $0.930^{+}$ & -1.602 & 0.781 & -1.675 & $1.087^{*}$ & -1.406 & $1.052^{*}$ & -1.688 \\
\hline & $(1.84)$ & $(-0.768)$ & $(1.528)$ & $(-0.788)$ & $(2.036)$ & $(-0.669)$ & $(1.967)$ & $(-0.804)$ \\
\hline \multirow[t]{2}{*}{ Pyramid } & -0.220 & $-1.163^{+}$ & $-0.242^{+}$ & -1.003 & -0.230 & -1.025 & -0.237 & $-1.071+$ \\
\hline & $(-1.6)$ & $(-1.864)$ & $(-1.72)$ & $(-1.508)$ & $(-1.574)$ & $(-1.621)$ & $(-1.612)$ & $(-1.704)$ \\
\hline \multirow[t]{2}{*}{ Level in Pyramid } & $0.265^{* *}$ & 0.182 & $0.261^{* *}$ & 0.050 & $0.249^{* *}$ & 0.136 & $0.252^{* *}$ & 0.151 \\
\hline & $(4.378)$ & $(0.579)$ & $(4.21)$ & $(0.136)$ & $(3.882)$ & $(0.422)$ & $(3.912)$ & $(0.474)$ \\
\hline \multirow[t]{2}{*}{ Cross-ownership } & $-0.305^{+}$ & -35.943 & -0.216 & -31.044 & $-0.357^{+}$ & -38.731 & $-0.375^{+}$ & -29.400 \\
\hline & $(-1.702)$ & $(0)$ & $(-1.201)$ & $(0)$ & $(-1.806)$ & $(-0.0)$ & $(-1.888)$ & $(0)$ \\
\hline \multirow[t]{2}{*}{$\log$ (assets) } & $-0.100^{* *}$ & $-0.191^{*}$ & $-0.090^{* *}$ & $-0.236^{*}$ & $-0.101^{* *}$ & $-0.219^{*}$ & $-0.095^{* *}$ & $-0.193^{*}$ \\
\hline & $(-4.389)$ & $(-2.134)$ & $(-3.62)$ & $(-2.362)$ & $(-3.924)$ & $(-2.266)$ & $(-3.68)$ & $(-2.02)$ \\
\hline \multirow[t]{2}{*}{ Listed } & -0.047 & $-4.333^{* *}$ & -0.069 & $-4.365^{* *}$ & -0.076 & $-4.304^{* *}$ & -0.081 & $-4.331^{* *}$ \\
\hline & $(-0.408)$ & $(-4.229)$ & $(-0.584)$ & $(-4.258)$ & $(-0.625)$ & $(-4.205)$ & $(-0.665)$ & $(-4.227)$ \\
\hline \multirow[t]{2}{*}{$\mathrm{GmbH}$} & -0.142 & $-2.500^{* *}$ & -0.124 & $-2.687^{* *}$ & -0.186 & $-2.516^{* *}$ & -0.184 & $-2.461^{* *}$ \\
\hline & $(-1.067)$ & $(-4.793)$ & $(-0.906)$ & $(-4.804)$ & $(-1.317)$ & $(-4.784)$ & $(-1.303)$ & $(-4.755)$ \\
\hline \multirow[t]{2}{*}{ Time Trend } & 0.002 & $0.420^{* *}$ & 0.004 & $0.433^{* *}$ & 0.022 & $0.428^{* *}$ & 0.025 & $0.410^{* *}$ \\
\hline & $(0.112)$ & $(4.323)$ & $(0.221)$ & $(4.349)$ & $(1.132)$ & $(4.263)$ & $(1.269)$ & $(4.098)$ \\
\hline \multicolumn{2}{|l|}{ Number of observations: } & 7,577 & & 7,332 & & 6,935 & & 6,926 \\
\hline \multicolumn{2}{|l|}{ Log likelihood: } & $-2,140.2$ & & $-2,061.4$ & & $-1,935.9$ & & $-1,929.3$ \\
\hline \multicolumn{2}{|c|}{ Wald Test against model $(1) \sim \chi_{2}^{2}$ : } & & & 0.651 & & 3.309 & & $6.859^{*}$ \\
\hline
\end{tabular}

Reference alternative: No change. Constants are included but not reported.

$* *, *,+$ : significantly different from zero at the $1,5,10$-percent level, respectively. 
Table 13: Data selection procedure

\begin{tabular}{lrr}
\hline \hline Selection criterion & Firms & Firm years \\
\hline Consolidated balance sheet data for the years 1986-1996 & 5,679 & 31,294 \\
Mining, manufacturing, construction, and trade & 3,751 & 20,614 \\
Two consecutive years of ownership data & 1,535 & 9,000 \\
Ownership information in the following year & 1,535 & 7,746 \\
No missing values & 1,510 & 7,577 \\
\hline \hline
\end{tabular}


Table 14: Definition of variables

Performance:

Total factor productivity Residual from OLS estimation of Cobb-Douglas production function, $y=\alpha k+\beta l$, with $y=\ln$ (total sales), $k=\ln$ (replacement costs of tangible assets) and $l=\ln$ (total number of employees). Sales and capital stock are deflated using appropriate price indices.

Return-on-assets (ROA) Earnings before interest and taxes (EBIT)/total assets

Stock market return Continuous yearly return $R_{t}^{c}=\sum_{w=1}^{n} \frac{R_{w}^{c}}{n} * 52$ with continuous weekly return $R_{w}^{c}=\ln \left(\frac{K_{w}^{p}}{K_{w-1}^{p}}\right)$ with $K_{w}^{p}$ performance value on Wednesday of week $w . K_{w}^{p}$ is corrected for capital changes, changes of stock's face value, stock splits, and dividend payments.

Cash flow on equity Year's result plus depreciation and interest payments divided by the book value of equity

Ownership structure:

Herfindahl index

$H=\sum_{j=1}^{n} P_{j}^{2}$, with $P_{j}$ size of individual block shareholder wins a vote, 0 otherwise: $\alpha=\Phi\left(\frac{C_{1}}{\sqrt{H-C_{1}^{2}}}\right)$

Control Control $=1$ if firm has ultimately controlling shareholder, calculated based on concept of control, 0 otherwise

Pyramid Pyramid $=1$ if ultimate owner is located on the second or higher level in the ownership structure

Level of control Level of the end of a control chain in pyramids. For example, Level $=1$ means that control resides with direct shareholder.

Cross-ownership Cross $=1$ if ultimate owner is part of the web of firms identified by Wenger and Kaserer (1998) and if ultimate owner indirectly owns share block in itself; 0 otherwise

Capital structure:

Debt-to-assets ratio

Total debt to total assets

Interest coverage EBIT divided by interest payments

No working capital $=1$ if short-term assets less short-term liabilities less than zero, $=0$ otherwise

Current ratio Short-term assets divided by short-term liabilities 
Figure 1: Herfindahl index and the probability of control transfers

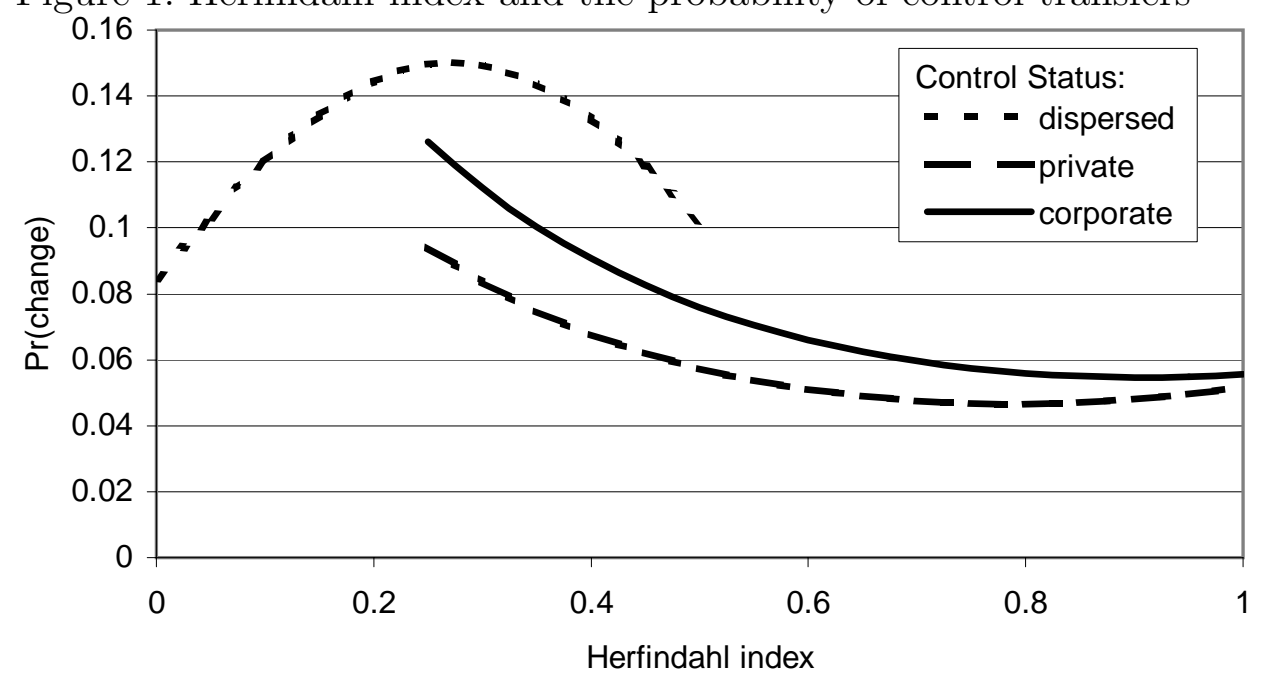

The figure shows the simulated probabilities of a transfer of control for the three types of initially controlling shareholders, given their actual characteristics and hypothetical values of the Herfindahl index. The lines are plotted for the range of Herfindahl index values between the 10th and the 90th percentiles of the observed values within the respective groups of firms. 
Figure 2: Contemporaneous correlation structure

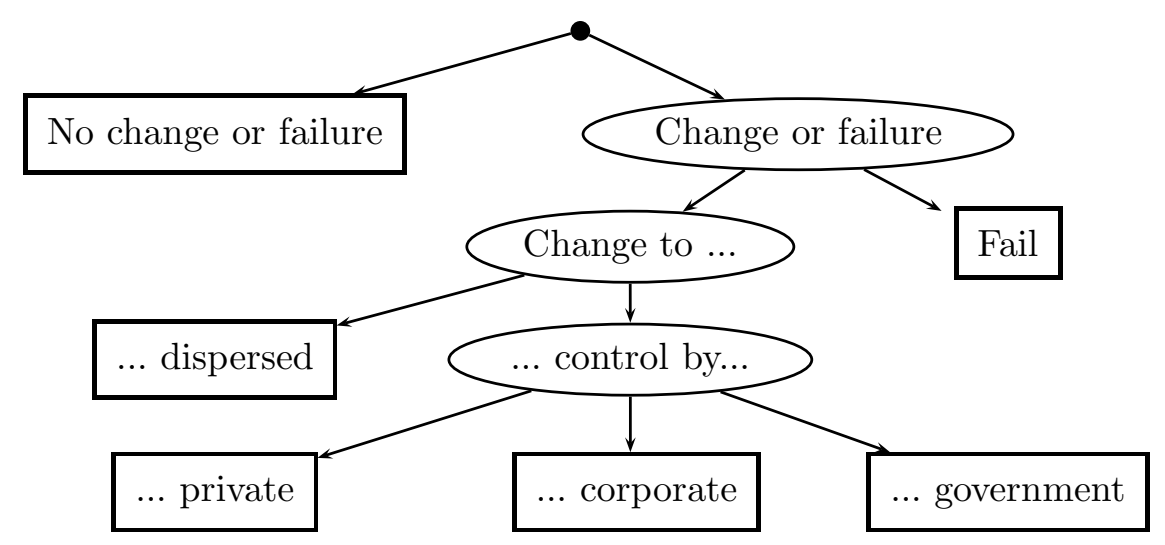




\section{Discussion Paper Series}

Mannheim Research Institute for the Economics of Aging Universität Mannheim

To order copies, please direct your request to the author of the title in question.

\begin{tabular}{|c|c|c|c|}
\hline Nr. & Autoren & Titel & Jahr \\
\hline 01-02 & Axel Börsch-Supan & $\begin{array}{l}\text { Eine Blaupause für eine nachhaltige } \\
\text { Rentenreform in Deutschland }\end{array}$ & 02 \\
\hline $02-02$ & Axel Börsch-Supan & A Blue Print For Germany's Pension Reform & 02 \\
\hline 03-02 & Axel Börsch-Supan & $\begin{array}{l}\text { Reduction of Working Time: Does it Decrease } \\
\text { Unemployment? }\end{array}$ & 02 \\
\hline 04-02 & Axel Börsch-Supan & $\begin{array}{l}\text { Übergang statt Untergang: Wider die Furcht vor } \\
\text { dem Untergang der Arbeit }\end{array}$ & 02 \\
\hline 05-02 & $\begin{array}{l}\text { Daniel Houser, } \\
\text { Joachim Winter }\end{array}$ & $\begin{array}{l}\text { How Do Behavioral Assumptions Affect Structural } \\
\text { Inference? Evidence Form A Laboratory } \\
\text { Experiment }\end{array}$ & 02 \\
\hline 06-02 & Axel Börsch-Supan & $\begin{array}{l}\text { International Comparison of Household Savings } \\
\text { Behaviour: The German Savings Puzzle }\end{array}$ & 02 \\
\hline 07-02 & \begin{tabular}{|l|} 
Tito Boeri, \\
Axel Börsch-Supan, \\
Guido Tabellini \\
\end{tabular} & $\begin{array}{l}\text { Would you Like to Reform the Pension System? } \\
\text { The Opinions of European Citizens }\end{array}$ & 02 \\
\hline $08-02$ & $\begin{array}{l}\text { Axel Börsch-Supan, } \\
\text { Florian Heiss, } \\
\text { Miki Seko } \\
\end{array}$ & $\begin{array}{l}\text { Housing Demand in Germany and Japan } \\
\text { Paper in memoriam of Stephen King }\end{array}$ & 02 \\
\hline $09-02$ & $\begin{array}{l}\text { Moshe Ben-Akiva, } \\
\text { Daniel McFadden, } \\
\text { Kenneth Train, } \\
\text { Axel Börsch-Supan, } \\
\text { et.al. }\end{array}$ & Hybrid Choice Models: Progress and Challenges & 02 \\
\hline $10-02$ & \begin{tabular}{|l} 
Axel Börsch-Supan, \\
Alexander Ludwig, \\
Joachim Winter \\
\end{tabular} & Aging and International Capital Flows & 02 \\
\hline $11-02$ & Axel Börsch-Supan & Labor market effects of population aging & 02 \\
\hline $12-02$ & Axel Börsch-Supan & $\begin{array}{l}\text { Kann die Finanz- und Sozialpolitik die } \\
\text { Auswirkungen der Bevölkerungsalterung auf den } \\
\text { Arbeitsmarkt lindern? }\end{array}$ & 02 \\
\hline 13-02 & $\begin{array}{l}\text { Florian Heiß, } \\
\text { Jens Köke }\end{array}$ & $\begin{array}{l}\text { Dynamics in ownership and firm survival: } \\
\text { Evidence from corporate Germany }\end{array}$ & 02 \\
\hline $14-02$ & Axel Börsch-Supan & $\begin{array}{l}\text { "Global Aging" an der Jahrtausendwende: } \\
\text { Die demographischen Herausforderungen des } \\
\text { 21. Jahrhunderts }\end{array}$ & 02 \\
\hline $15-02$ & Axel Börsch-Supan & $\begin{array}{l}\text { Nach der Reform ist vor der Reform: Weitere } \\
\text { Schritte für eine nachhaltige Reform der } \\
\text { Altersvorsorge in Deutschland }\end{array}$ & 02 \\
\hline $16-02$ & Florian Heiss & Specification(s) of Nested Logit Models & 02 \\
\hline
\end{tabular}




\begin{tabular}{|l|l|l|c|}
\hline $17-02$ & Axel Börsch-Supan & $\begin{array}{l}\text { What We Know and What We Do NOT Know } \\
\text { About the Willingness to Provide Self-Financed } \\
\text { Old-Age Insurance }\end{array}$ & 02 \\
\hline $18-02$ & $\begin{array}{l}\text { Axel Börsch-Supan, } \\
\text { Agar Brugiavini }\end{array}$ & Savings: The Policy Debate in Europe & 02 \\
\hline
\end{tabular}

